AperTO - Archivio Istituzionale Open Access dell'Università di Torino

\title{
Going Beyond Test Scores: The Gender Gap in Italian Children's Mathematical Capability
}

\section{This is a pre print version of the following article:}

Original Citation:

\section{Availability:}

This version is available http://hdl.handle.net/2318/1677369

since 2021-07-20T15:22:58Z

Published version:

DOI:https://doi.org/10.1080/13545701.2021.1908574

Terms of use:

Open Access

Anyone can freely access the full text of works made available as "Open Access". Works made available under a Creative Commons license can be used according to the terms and conditions of said license. Use of all other works requires consent of the right holder (author or publisher) if not exempted from copyright protection by the applicable law. 


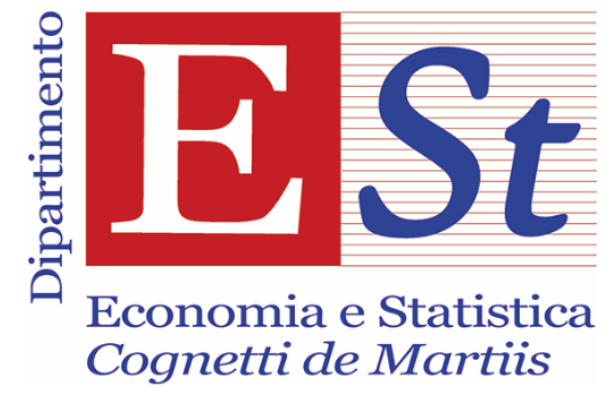

\section{Working Paper Series}

\section{THE GENDER GAP IN ATTITUDES AND TEST SCORES: A NEW CONSTRUCT OF THE MATHEMATICAL CAPABILITY.}

MARIA LAURA DI TOMMASO, ANNA MACCAGNAN and SILVIA MENDOLIA 



\title{
The Gender Gap in Attitudes and Test Scores: a new construct of the mathematical capability.
}

\author{
Di Tommaso Maria Laura ${ }^{1}$, Maccagnan Anna², Mendolia Silvia ${ }^{3}$
}

\begin{abstract}
In most OECD countries, girls outperform boys in all subjects except mathematics. Usually, only test scores are utilised as a measure of mathematical skills. In this paper, we argue that in order to measure children's capability in mathematics we need to include some indicators of the attitudes of children towards the subject. This is particularly important when we analyse gender gaps, because attitudes towards mathematics differ by gender. We first describe the differences by gender both in test scores and attitudes utilising a model including school fixed effects. Next, we estimate a quantile regression in order to analyse how the gender gap varies across the distribution of the attitudes. Lastly, in addition to the test scores in mathematics, we use indicators of attitudes towards maths to estimate a Structural Equation Model, which takes into account that maths capability is a latent construct of which we only observe some indicators (test scores and attitudes). We use data from the Italian National Test (Invalsi) for year 5 and year 10 in 2014 and 2015. Results confirm that when we measure mathematics capability including attitudes in addition to test scores, the gap between boys and girls is even wider with respect to the analysis of test scores alone, and therefore educational policies aimed at reducing the gender gap in mathematics should address both attitudes and test scores.
\end{abstract}

JEL: J16; I24; C31.

Keywords Maths gender gap, Attitudes, Structural Equation models, school achievement.

\footnotetext{
${ }^{1}$ Dept of Economics and Statistics Cognetti de Martiis, Lungo Dora Siena 100, Torino, Italy; Collegio Carlo Alberto, Torino, Italy; Frisch Center for Economic Research, Oslo. marialaura.ditommaso@unito.it

${ }^{2}$ University of Exeter Medical School, European Centre for Environment and Human Health, Knowledge Spa, Royal Cornwall Hospital Truro, TR1 3HD, UK. a.maccagnan@exeter.ac.uk

${ }^{3}$ School of Accounting, Economics, and Finance, University of Wollongong, Northfields Avenue, North Wollongong, NSW 2522. smendoli@uow.edu.au
} 


\section{Introduction and literature review}

Girls outperform boys in educational outcomes in most subjects, both in Italy and in other OECD countries. Girls have higher grades since primary school and they graduate with higher scores in all subjects, including STEM (Science Technology Engineering and Mathematics) ones (OECD, 2015). Nevertheless, in some OECD countries and particularly in Italy, girls have lower test scores than boys in mathematics both in primary and secondary school. This gender gap in mathematics is policy relevant because it can lead to an under-representation of girls in the STEM subjects in universities and an under-representation of women in highly technological and innovative labour markets that also yield high wages (European Commission 2006, 2012, 2015; National Academy of Science, 2007). Therefore the gender gap in mathematics in favour of boys is a matter of concerns for policies addressing gender equality.

The gender gap in mathematics for Italian students is one of the highest among OECD countries, according to the latest PISA results (a 20 point difference in Italy against an average difference of 9 points in the OECD, OECD 2016), even if the overall average in Maths test scores for Italian students is aligned to the OECD average results. Similar results also emerge from TIMMS 2015 (Trends in International Mathematics and Science Study) showing that the gender gap in mathematics for Italian children in fourth grade is the highest among all countries included in the survey (Mullis et al 2016). Contini et al (2017) show that boys outperform girls in mathematics from $2^{\circ}$ to $10^{\circ}$ grade, using the National Assessment for Italy (INVALSI) . Further, the gender gap in mathematics is increasing with age, even after controlling for individual and family characteristics.

A variety of explanations have been proposed for the existence of a gender gap in mathematics. Some studies point to the role of parents' and teachers' beliefs about the innate mathematical abilities of boys and girls ${ }^{4}$, others to the role of cognitive and non-cognitive abilities ${ }^{5}$. Although the causal direction is difficult to assess, girls display less maths self-efficacy (self-confidence in solving maths related problems) and maths self-concept (belief in their own abilities), and more anxiety and stress in doing maths related activities boys (Else-Quest, Hyde, \& Linn, 2010). Lubiensky et al (2013) used data from USA (ECLS-K) for Grade 3 and 5 and found that gender gaps in mathematical confidence were substantially larger than gaps in actual performance, with disparities in interest being smallest of all. These findings are consistent with TIMSS and PISA reports of girls throughout the world

${ }^{4}$ See among others, Fryer and Levitt. (2010).

${ }^{5}$ See among others: Heckman, J. J. \& T. Kautz (2012); Heckman, J. J. \& T. Kautz (2014). 
having substantially less mathematical confidence than boys (Mullis et al 2008; OECD 2016). There is a vast economic literature on the determinants of human capital formation during childhood. It is becoming increasingly clear that human capital is a complex object with many different dimensions. A large and growing body of evidence points to the importance of both cognitive and non-cognitive skills and to their interaction ${ }^{6}$.

The concept of attitudes towards mathematics has been defined in the context of mathematics education ${ }^{7}$. The origin of the "attitude” comes from social psychology (Allport 1935) in the context of predicting choices based on preferences like buying goods or voting. Early studies about attitude in mathematics education are placed in this framework, and focus on the relationship between attitude towards mathematics and school mathematics achievement, trying to highlight a causal relationship. As Neale (1969, p. 631) underlines: “Implicit (...) is a belief that something called 'attitude' plays a crucial role in learning mathematics. (...) positive attitude toward mathematics is thought to play an important role in causing students to learn mathematics.” Nevertheless, a large portion of studies about attitudes do not provide a clear definition of the construct itself: often attitude is defined implicitly and a posteriori through the instruments used to measure it (Leder 1985; McLeod 1992; Ruffell et al. 1998; Daskalogianni and Simpson 2000). Further, studies that explicitly give a definition of attitude do not share a single definition. In the variety of meanings attributed to the construct, three main different types may be identified: (a) A simple definition that describes attitude as the positive or negative degree of affect associated with mathematics (Haladyna et al. 1983); (b) A tripartite definition that recognises three components in attitude: emotional response towards mathematics, beliefs regarding mathematics and behaviour related to mathematics (Hart 1989); (c) A bidimensional definition in which, with respect to the previous one, behaviours do not appear explicitly (Daskalogianni and Simpson 2000).

Another critical point in research on attitude towards mathematics, related to the choice of a definition, is its measurement. Surveys generally propose items like: 'Mathematics is useful', 'I like problem solving', 'I think about arithmetic problems outside school'. Since these items are related to the three different dimensions — respectively beliefs, emotions, and behaviours — questionnaires make implicit reference to the tripartite model. Di Martino and Zan (2010) investigated how students tell their own relationship with mathematics, proposing the essay "Me and maths" to more than 1,600 students (1st to 13th grade). Students' attitude towards mathematics comes out as a multidimensional construct. The study also shows how the relationship with mathematics is rarely told as stable, even

\footnotetext{
${ }^{6}$ For a complete review and an updated state of the art see: Attanasio O. P. (2015). See also, Newcombe, N.S., Levine, S.C. \& Mix, K. S. (2015).

${ }^{7}$ A good review of the literature can be found in Larsen 2013 and in Di Martino and Zan 2010.
} 
by older students. Their result suggests that there is scope for policies that change attitudes over children life course.

This paper defines a mathematical capability of children, which includes both test scores in mathematics and attitudes towards mathematics. We refer to the theoretical construct of the capability approach of Amartya Sen and to the economics of education literature on the importance of cognitive and non-cognitive skills (Heckman 2008; Cunha et al. 2010; Sikora and Pokropek 2012; Cornwell et al. 2013; Gutman and Schoon 2013; Heckman and Mosso 2014) in order to show that the use of test scores is limited and it is important to include other non-cognitive dimensions related to mathematics.

The capability approach (Sen 1985, 1999, 2009; Nussbaum 2003) represents an alternative framework for the evaluation of human well-being, which does not primarily focuses on income and wealth, but also includes other important dimension of well-being such as education, bodily integrity, social interactions etc. (Sen 2009). Similarly, we define a mathematical capability as including the dimension of test scores as well as the dimension of attitudes towards the subject. This is particularly important for analysing gender gaps because in addition to a gender gap in test scores, there is also a gender gap in attitudes. We use the questions related to the attitudes towards mathematics included in Italian National Test (Invalsi) data for year 5 (fifth year of primary school) and for year 10 (second year of secondary school). These questions relate both to beliefs (I am usually good at maths, I learn maths easily, maths is harder for me, I learn a lot of things in maths) and emotions (I like maths, maths is boring) but not behaviours. Therefore, with respect to the different definitions provided above, the Italian National Test utilises a bi-dimensional definition of attitudes.

We begin by describing the differences by gender both in test scores and attitudes using an OLS model with school fixed effects. Next, we estimate a quantile regression for attitudes, in order to analyse how the gender gap varies along the distribution of attitudes. Lastly, in addition to the test scores in mathematics, we use indicators of attitudes towards maths to estimate a Structural Equation Model which takes into account that maths capability is a latent constructs of which we only observe some indicators (test scores and attitudes). Results confirm that when we measure mathematics capability including attitudes in addition to test scores, the gap between boys and girls is even wider with respect to the analysis of test scores alone.

\section{Data and descriptive statistics}


Education starts in Italy at age 6. Primary school lasts for 5 years (until age 11) and is followed by 3 years of middle school and 5 years of secondary school. Compulsory education terminates at 16 years old.

Students choose among different types of high school at age 13. There are three main types of secondary schools with substantial differences in the curricula: the Lyceum, the Technical High School and the Vocational High School. Lyceums offer a higher level of academic education with strong focus on the humanities, sciences, languages or arts. Technical institutes provide a general education and a qualified technical specialization in a particular field. Vocational institutes have the objective to prepare students for entering the labour force.

We use data from the National Test INVALSI. In general, INVALSI tested all Italian children in grade 2, 5, 8, and 10 since 2010 and covers the whole population of Italian students. However, we use data from a sub-sample which includes students who took the test under the supervision of an external inspector ${ }^{8}$.

The estimation sample only includes native children, because migrants are more likely to repeat and/or to be enrolled in lower grades with respect to their age due to their lack of proficiency in Italian (Contini et al., 2017).

In addition to test scores, in selected years, INVALSI data includes information about attitudes towards maths, including six questions asking students how much they like maths, as well as more specific questions about their learning, confidence and understanding of the subject.

In this study, we use data from grade 5 and grade 10 for the years 2014 and 2015, which are the only datasets including information on attitudes towards maths. ${ }^{9}$ These questions relate both to beliefs and emotions. Table A1 and A2 in appendix present descriptive statistics for attitudes towards maths in the estimation sample. In particular, for grade 5 the following six items are included in the survey: I am usually good at maths, I learn maths easily, Maths is harder for me than for most of my class mates, I learn lots of things in maths, I like studying maths, Maths is boring. The first two items relate to the dimension of "beliefs" while the last two items to the dimension of emotions. To each statement the pupils had to reply on a Likert scale from 1 to 4, where 1 indicates "strongly disagree” and 4 "strongly agree”. For grade 10, the items are the following: I learn maths quickly, I learn lots of things in maths, I have always thought maths is one of my strongest subject, During maths class I

\footnotetext{
${ }^{8}$ For a detailed explanation of the problem of “cheating” in Invalsi data see Angrist et al (2015), Bertoni et al. (2013), Lucifora and Tonello (2015), Paccagnella and Sestito (2014)

${ }^{9}$ There also is some data for attitudes in year 2013 but it includes different questions respect to 2014 and 2015 and therefore has not been considered in this analysis.
} 
understand the hardest topic, I like studying maths, Maths is boring. The first four items belong to the dimension of beliefs while the last two refer to the dimension of emotions. Tables A1 and A2 show that there is a gender gap in all items for attitudes towards maths and that girls are less likely to like maths and have less confidence in their ability to learn maths effectively. These differences are significantly different from zero. Further, the proportion of students who think that maths is harder for them than for their peers is substantially higher for girls than for boys, and girls are less likely to believe that maths is one of their strongest subjects ${ }^{10}$.

Given that the focus of this paper is the analysis of a construct of mathematical capability, including both test scores and attitudes towards mathematics, we begin the analysis by describing the relationship between test scores and attitudes through a graphical analysis. Figures 1 to 4 show the average standardised test scores by answers to the questions on attitudes and by gender. As expected, both boys and girls who express strong preferences for mathematics have on average higher test scores than their peers who do not like the subject. However, the gender differences are noticeable, even among students with strong preference for the subject. For instance, Figure 1 shows that the average standardised test scores for boys in grade 5 in 2014, who answer that they strongly like studying maths is around 0.2 standard deviations, while the same figure for girls is only around 0.1 s.d. So even among pupils who have a strong preference for mathematics, there is a difference in test scores, with boys consistently outperforming girls. This pattern is observed in all the four cohorts, and across all the different questions about preference for mathematics.

In order to analyse the relationship between attitudes and test scores, we construct a single indicator of attitudes towards maths using factor analysis and the students' answers to these six questions regarding their emotions and beliefs in maths (see table A3 in Appendix A). Table 1 reports descriptive statistics of this index for attitudes and the standardised test score. Both indexes are standardised to have mean equal 0 and standard deviation equal 1 . The gender gap in attitudes is always higher than the gender gap in test scores, except than for grade 10 in 2015.

\section{Year $52014 \quad$ Year $52015 \quad$ Year $102014 \quad$ Year 102015}

\begin{tabular}{lllll}
\hline Attitudes towards maths & $0(1)$ & $0(1)$ & $0(1)$ & $0(1)$ \\
Mean (SD) & -3.00 & -2.95 & -1.57 & -1.61 \\
Minimum & 1.12 & 1.29 & 1.83 & 1.99 \\
Maximum & & & & \\
Attitudes towards maths - Girls & & & & \\
\hline
\end{tabular}

${ }^{10}$ We have also performed a preliminary descriptive analysis of girls' attitudes towards Italian and we found that girls report higher preferences than boys for this subject. 


\begin{tabular}{lllll}
\hline $\begin{array}{l}\text { Mean (SD) } \\
\text { Attitudes towards maths - Boys }\end{array}$ & $-0.15(1.01)$ & $-0.14(1.00)$ & $-0.13(1.00)$ & $-0.09(1.00)$ \\
$\begin{array}{llll}\text { Mean (SD) } \\
\text { Gender gap in attitudes }\end{array}$ & $-0.15(0.96)$ & $0.13(0.97)$ & $0.12(0.98)$ & $0.10(0.98)$ \\
\hline $\begin{array}{l}\text { Standardized maths test scores } \\
\text { Mean (SD) }\end{array}$ & $0(1)$ & $-0.27^{* * *}$ & $-0.25^{* * *}$ & $-0.19^{* * *}$ \\
$\begin{array}{l}\text { Minimum } \\
\text { Maximum }\end{array}$ & -3.53 & $0(1)$ & $0(1)$ & $0(1)$ \\
$\begin{array}{l}\text { Standardized maths test scores - Girls } \\
\text { Mean (SD) }\end{array}$ & $-0.07(0.97)$ & -2.64 & -3.12 & -2.03 \\
$\begin{array}{l}\text { Standardized maths test scores- Boys } \\
\text { Mean (SD) }\end{array}$ & $0.06(1.02)$ & $0.09(1.02)$ & $0.08(1.04)$ & $0.17(1.01)$ \\
Gender gap in test scores & & & & -0.02 \\
\hline
\end{tabular}

\section{Table 1 - Gender gap (G-B) in attitudes towards maths and test scores}

Note: * indicates that the underlying coefficient is significant at $10 \%$ level, ** at $5 \%$ and $* * *$ at $1 \%$.

Figures 5 to 8 present the cumulative density functions of the indicator of attitudes towards maths, by gender. The distribution of the index in all four cohorts clearly shows evidence of a gender gap in attitudes towards mathematics, with boys generally showing a higher level of preference for the subject.

Figures 7 and 8 present the distribution of the attitudes index in grade 10, by gender. The proportion of students who do not like maths increases with respect to grade 5 . However, girls continue to appear less confident and show lower average values of the index of attitudes towards mathematics in both year 10 cohorts.

Figures 9 and 10 show the relation between the index of attitudes and standardised test scores for grade 5 and grade 10 in year 2014 and year $2015^{11}$. In general, girls have lower level of attitudes towards maths, even if their test scores are equal to those of boys. The only exception is represented by students in year 10 in 2015. In this case, for low levels of test scores, girls show lower levels of attitudes than equally performing boys, but they show higher level of attitudes at high levels of test scores.

INVALSI data also includes parental characteristics and family background, collected from a students' survey and from school board records. In selected years, INVALSI provides a synthetic indicator of economic and socio-cultural status (ESCS) similar to that the one available in PISA. The

\footnotetext{
11 The graphs have been estimated using a locally weighted regression of attitudes towards maths on test scores (command lowess in STATA).
} 
ESCS index is calculated by taking into consideration parental educational background, employment and occupation, and home possessions.

The complete set of descriptive statistics for the variables used in the estimation is provided in table A4 in appendix A.

\section{Modelling strategies}

\subsection{Linear cross section model, school fixed effects and quantile regression}

Test scores are not measured on the same scale at different school years, and therefore the gender gap on the attitudes towards maths is not comparable across grades. For this reason, we use standardized test scores and the index of attitudes towards maths is standardized (has mean equal to zero and variance equal to one), and therefore the gender gap results show the difference in standard deviations between girls and boys.

We begin our analysis by focusing on the total effect of gender on average maths achievement and attitudes towards maths. We estimate separate OLS models in order to capture the average effect of gender and a set of control variables, including maternal and paternal education, socio-economic status of the family, and geographical area, on test scores and attitudes. We use both the single items for attitudes and the synthetic index for attitudes presented in section 2.

Second, it is important to consider the role of school characteristics in affecting children' learning and the effect of gender might operate both indirectly via school choices and directly net of school characteristics. Students attending the same school are exposed to similar teaching practices, learning targets, and peer characteristics (including socio-economic status, gender, and ability). All of these factors may have a separate effect on students' achievements and attitudes, and may affect the gender gap in test scores and attitudes in a specific way (Contini et al., 2017). For this reason, we estimate the direct effects of gender on maths achievement and attitudes estimating two models including school fixed effects, which exploit within-school variability, and deliver valid estimates of the gender gap given individual controls and (observed and unobserved) school characteristics. Therefore, the impact of gender on test scores and on maths attitudes is estimated as follows:

$$
y_{i j t}=\alpha+\beta g_{i}+\gamma^{\prime} x_{i t}+u_{j}+\varepsilon_{i t}
$$

Where $y_{i j t}$ represents the outcome of interest (maths test scores or attitudes towards maths) for individual $i$ attending school $j$ at time $t, \beta$ is the coefficient of interest (capturing the impact of students' gender on the outcome), $\mathrm{x}_{\mathrm{it}}$ is a vector of individual and family characteristics, $\mathrm{u}_{\mathrm{j}}$ is a school 
fixed effect (capturing all time invariants school characteristics, which may have an impact on students' learning and attitudes) and $\varepsilon_{i t}$ is an individual specific error term.

Last, we focus on the role of gender on attitudes towards maths, and analyse the effect of gender on the entire distributions of the index using quantile regression models (Koenker and Basset, 1978). In practice, we investigate the gender gap at different percentiles of the distribution of the attitudes index, and assess whether female's disadvantage exists throughout the distribution, or instead is stronger among children with very high or very low preference for mathematics. In the simplest case where gender is the only explanatory variables, the quantile regression coefficient gives the difference between the level of attitudes of girls and boys at a specific percentile of the index distribution. The estimated quantile regression includes the same set of independent variables used in the OLS models.

\section{2 Modelling strategy for the Mathematical Capability}

The existence of multiple, inter-related indicators to measure mathematical capability raises the question of how to combine them in empirical research. The Multiple Indicators Multiple Causes (MIMIC) model developed in this paper represents one possible approach to solve this problem. One basic strategy could be to choose a single indicator we believe is the closest (replies to the question: "I like maths", for example) to the unobserved construct (mathematical capability), and ignore both measurement error and information on the remaining indicators.

Alternatively, we could use the information in all indicators by creating a synthetic variable, such as a simple mean indicator. The resulting Ordinary Least Squares model represents perhaps the most restrictive model given the neglect of measurement error and the reduction of many indicators to a single one.

Instead, in this approach, we assume that each indicator is a component of mathematical capability; and maths capability is an unobserved variable that is linked to the observable indicators. The principal advantage of this approach is that it does not rely on exact measurement of attitudes. Each indicator represents a noisy signal of attitudes towards maths. This modelling strategy has been extensively used in psychometrics (Edwards and Bagozzi, 2000) and is founded upon the specification of a system of equations which specify the relationship between an unobservable latent variable (maths capability), a set of observable endogenous indicators and a set of observable exogenous variables. 
This approach builds upon the early work of Joreskog and Goldeberger (1975) and Zellner $(1970)^{12}$. The Multiple Indicators and Multiple Causes (MIMIC) approach allows us to think of this model as comprising two parts: a structural equation for mathematical capability and a measurement equation that takes into account that there is no single variable called maths capability. For each of the indicators, a weight (a factor loading) will be estimated. This weight represents how much that specific indicator counts in explaining the capability respect to other indicators.

The structure of the model is as follows:

$$
Y=\Lambda^{Y} y^{*}+\varepsilon, j=1, \ldots \ldots ., m
$$

where

$Y=\left(Y_{1}, Y_{2}, Y_{3}, \ldots \ldots \ldots . . Y_{m}\right)^{\prime}$ is a $m \times 1$ vector with each element representing an indicator of maths capability, denoted $Y^{*} . \Lambda^{Y}=\left\{\Lambda_{1}^{Y}, \Lambda_{2}^{Y}, \Lambda^{Y}{ }_{3} \ldots . . \Lambda^{Y}{ }_{j}\right\}^{\prime}$ denotes a $m \times 1$ parameter vector of factor loadings, with each element representing the expected change in the respective indicator following a one unit change in the latent variable. $\varepsilon$ is a $m \times 1$ vector of measurement errors, with $\Theta_{\varepsilon}$ denote the covariance matrix.

In addition we posit that maths capability is linearly determined by a vector of observable exogeneous variables $x=\left(x_{1}, x_{2}, \ldots . . x_{s},\right)^{\prime}$ and a stochastic error $\varsigma$ giving,

$$
Y^{*}=x^{\prime} \gamma+\varsigma
$$

where $\gamma$ is a $s \times 1$ vector of parameters.

Examining (2) and (3) we may think of our model as comprised of two parts: (3) is the structural equation and (2) is the measurement equation reflecting that the observed measurements are imperfect indicators. The structural equation specifies the relationship between the observed exogeneous causes and the latent construct attitudes towards mathematics. Since $Y^{*}$ is unobserved, it is not possible to recover direct estimates of the structural parameters $\gamma$. Combining (2) and (3) the reduced form representation is written as

\footnotetext{
${ }^{12}$ Excellent review of the literature is to be found in Bentler and Weeks (1980) and Aigner, Hsiao, Kapteyn, and Wansbeek (1984).
} 
$y=\pi x+v$

where $\pi=\Lambda^{Y} \gamma^{\prime}$ is the $m \times s$ reduced form coefficient matrix and $v=\Lambda^{Y} \varsigma+\varepsilon$ is the reduced form disturbance.

In our case the indicators are the 6 items for attitudes and test scores (described in section 2 above). The exogenous variables are gender, an indicator of the socio-economic status of the parents, geographical area, father and mother education and type of high school for grade 10 (descriptive statistics for the exogenous variables are presented in Tab. A4).

\section{Results}

\subsection{Results from cross-sectional linear models and school fixed effects}

We begin by exploring the gender gap in attitudes toward mathematics and present estimates of the effect of gender on the different items included in the maths attitudes indicator. We present results estimated using OLS, and OLS with school fixed effects ${ }^{13}$. Table 2 present results for each of the four cohorts included in the analysis. Overall, the gender gap is higher in the questions capturing maths self-confidence, such as "I am usually good at maths"; "I learn maths easily" (in year 5); "I have always thought maths is one of my strongest subject"; and "During maths classes I understand the hardest topics"; (in year 10). The impact of gender on these variables ranges from $20 \%$ to $30 \%$ of a standard deviation in year 5, and from 20 to $25 \%$ of a standard deviation in year 10 . The gender gap is also high for the question "I like studying maths" for students in year 5 (around 30\% of the standard deviation). On the other hand, the gender gap is much smaller in the questions capturing attitudes towards the learning process ("maths is boring" or "I learn lots of things in maths", where the gap is the lowest across all four cohorts), where the impact is usually around $10 \%$ of a standard deviation.

\footnotetext{
${ }^{13}$ We have also estimated an ordered probit given that the items for attitudes vary on a Likert scale 1 to 4 . Results are very similar to the OLS and are available from the authors upon request.
} 
Table 2 - The gender gap in attitudes towards maths.

\begin{tabular}{|c|c|c|c|c|}
\hline & Year 52014 & Year 52015 & Year 102014 & Year 102015 \\
\hline $\begin{array}{l}\text { I like studying maths } \\
\text { OLS } \\
\text { School FE }\end{array}$ & $\begin{array}{l}-0.320(0.014)^{* * *} \\
-0.320(0.014)^{* * *}\end{array}$ & $\begin{array}{l}-0.282(0.015)^{* * *} \\
-0.280(0.015)^{* * *}\end{array}$ & $\begin{array}{l}-0.174(0.012)^{* * *} \\
-0.047(0.012)^{* * *}\end{array}$ & $\begin{array}{c}-0.142(0.013)^{* * * *} \\
0.008(0.015)\end{array}$ \\
\hline $\begin{array}{l}\text { I learn maths easily } \\
\text { OLS } \\
\text { School FE }\end{array}$ & $\begin{array}{l}-0.292(0.012)^{* * *} \\
-0.294(0.012)^{* * *}\end{array}$ & $\begin{array}{l}-0.262(0.013)^{* * *} \\
-0.259(0013)^{* * *}\end{array}$ & NA & NA \\
\hline $\begin{array}{l}\text { Maths is harder for me than } \\
\text { for most of my class mates } \\
\text { OLS } \\
\text { School FE }\end{array}$ & $\begin{array}{l}-0.217(0.013)^{* * *} \\
-0.215(0.013)^{* * *}\end{array}$ & $\begin{array}{l}-0.173(0.015)^{* * *} \\
-0.177(0.015)^{* * *}\end{array}$ & NA & NA \\
\hline $\begin{array}{l}\text { I am usually good at maths } \\
\text { OLS } \\
\text { School FE }\end{array}$ & $\begin{array}{l}-0.334(0.011)^{* * *} \\
-0.338(0.011)^{* * *}\end{array}$ & $\begin{array}{l}-0.249(0.0011)^{* * *} \\
-0.2480 .0011)^{* * *}\end{array}$ & NA & NA \\
\hline $\begin{array}{l}\text { I learn lots of things in maths } \\
\text { OLS } \\
\text { School FE }\end{array}$ & $\begin{array}{l}-0.096(0.011)^{* * *} \\
-0.096(0.011)^{* * *}\end{array}$ & $\begin{array}{l}-0.064(0.012)^{* * *} \\
-0.057(0.012)^{* * *}\end{array}$ & $\begin{array}{l}-0.163(0.011)^{* * *} \\
-0.052(0.012)^{* * *}\end{array}$ & $\begin{array}{l}-0.102(0.012)^{* * * *} \\
0.002(0.013)\end{array}$ \\
\hline $\begin{array}{l}\text { Maths is boring } \\
\text { OLS } \\
\text { OLS FE }\end{array}$ & $\begin{array}{l}-0.127(0.013)^{* * *} \\
-0.128(0.013)^{* * *}\end{array}$ & $\begin{array}{l}-0.141(.015)^{* * * *} \\
-0.135(0.015)^{* * *}\end{array}$ & $\begin{array}{l}-0.061(0.012)^{* * *} \\
0.057(0.014)^{* * *}\end{array}$ & $\begin{array}{l}-0.037(0.014)^{* * *} \\
0.100(0.015)^{* * *}\end{array}$ \\
\hline $\begin{array}{l}\text { I learn maths quickly } \\
\text { OLS } \\
\text { OLS FE }\end{array}$ & NA & NA & $\begin{array}{l}-0.309(0.012)^{* * *} \\
-0.210(0.013)^{* * *}\end{array}$ & $\begin{array}{l}0.223(0.013)^{* * *} \\
-0.121(0.015) * * *\end{array}$ \\
\hline $\begin{array}{l}\text { I have always thought maths is } \\
\text { one of my strongest subject } \\
\text { OLS } \\
\text { OLS FE }\end{array}$ & NA & NA & $\begin{array}{l}-0.362(0.012)^{* * *} \\
-0.244(0.013)^{* * * *}\end{array}$ & $\begin{array}{l}-0.325(0.014)^{* * * *} \\
-0.193(0.016)^{* * *}\end{array}$ \\
\hline $\begin{array}{l}\text { During maths classes I } \\
\text { understand the hardest topics } \\
\text { OLS } \\
\text { OLS FE }\end{array}$ & NA & NA & $\begin{array}{l}-0.317(0.011)^{* * *} \\
-0.223(0.013)^{* * *}\end{array}$ & $\begin{array}{l}-0.239(0.014)^{* * *} \\
-0.140(0.014)^{* * *}\end{array}$ \\
\hline
\end{tabular}

Note: Std errors are in brackets. * indicates that the underlying coefficient is significant at $5 \%$ level, $* *$ at $1 \%$ and $* * * 0.1 \%$. All models include area of residence, maternal and paternal education, ESCS index (Socio-economic indicator). Models for year 10 include also the type of high school (Lyceum, Professional or Vocational)

Tables 3 and 4 shows estimates of the gender gaps in maths achievements and attitudes calculated using OLS, and OLS with school fixed effects. Gender has a significant and sizable effect on test scores and attitudes towards in mathematics both in year 5 and in year 10. Results are very stable when we control for school fixed effects, implying that there is no substantial indirect effect of gender via school characteristics, not even at year 10, where schools differ markedly and the choice between school types is strongly related to individual and family characteristics. Overall, table 3 shows that the gender gap in maths attitudes is around $20 \%-30 \%$ of a standard deviation of the index (the index for maths attitudes is standardised to have mean 0 and variance equal to 1). To put this in context, this is around at least 3 times the impact of a 
standard deviation increase in socio-economic disadvantage (captured by the ESCS index, see table A5). The gap in maths attitudes is slightly lower (but still relevant in size and significance) in year 10 once we control for school fixed effects, and this probably reflects the effect of students' self- selection into different types of high school.

The gender gap in test scores ranges between $15 \%$ and $45 \%$ of a standard deviation, and increases in year 10 (see table 4). Interestingly, the effect of gender on maths test scores persists in year 10, even after we control for school type. Therefore, our results show the existence of a substantial gender gap that persists even after we take into account the fact that boys and girls could self-select into different high schools (see Contini et al., 2017, for an in-depth discussion of the gender gap in test scores). We have also investigated the gender gap in attitudes by social economic status and grade distribution and results have confirmed that the gap persists in all different groups ${ }^{14}$.

Table 3 - The gender gap (G-B) in maths attitudes: gender coefficients in OLS and School Fixed Effect models

\begin{tabular}{lcccc}
\hline & Year 5 2014 & Year 5 2015 & Year 10 2014 & Year 10 2015 \\
\hline \multirow{2}{*}{ OLS } & $-0.326^{* * *}$ & $-0.279^{* * *}$ & $-0.285^{* * *}$ & $-0.254^{* * *}$ \\
& $(0.013)$ & $(0.015)$ & $(0.012)$ & $(0.014)$ \\
\multirow{2}{*}{ School FE } & $-0.327^{* * *}$ & $-0.277^{* * *}$ & $-0.144^{* * *}$ & $-0.071^{* * *}$ \\
& $(0.013)$ & $(0.014)$ & $(0.012)$ & $(0.015)$ \\
\hline $\mathrm{N}$ & 22,246 & 18,231 & 31,644 & 22,772 \\
\hline
\end{tabular}

Note: Std errors are in brackets. * indicates that the underlying coefficient is significant at $5 \%$ level, $* *$ at $1 \%$ and $* * * 0.1 \%$. All models include area of residence, maternal and paternal education, ESCS index (Socio-economic indicator). Models for year 10 include also the type of high school (Lyceum, Professional or Vocational)

\footnotetext{
${ }^{14}$ Results are available from the authors upon request.
} 
Table 4 - The gender gap (G-B) in maths test scores: gender coefficient in OLS and School Fixed Effect models.

\begin{tabular}{lcccc}
\hline & Year 5 2014 & Year 5 2015 & Year 10 2014 & Year 10 2015 \\
\hline OLS & $-0.132^{* * *}$ & $-0.204^{* * *}$ & $-0.339^{* * *}$ & $-0.467 * * *$ \\
& $(0.013)$ & $(0.014)$ & $(0.010)$ & $(0.012)$ \\
School FE & $-0.141^{* * *}$ & $-0.197^{* * *}$ & $-0.165^{* * *}$ & $-0.306^{* * *}$ \\
& $(0.012)$ & $(0.013)$ & $(0.009)$ & $(0.011)$ \\
\hline $\mathbf{N}$ & 22,246 & 18,231 & 31,644 & 22,772 \\
\hline
\end{tabular}

Note: Std errors are in brackets. * indicates that the underlying coefficient is significant at $5 \%$ level, $* *$ at $1 \%$ and $* * * 0.1 \%$. All models include area of residence, maternal and paternal education, ESCS index (Socio-economic indicator). Models for year 10 include also the type of high school (Lyceum, Professional or Vocational).

We also estimate the impact of gender on attitudes using quantile regressions. Results are presented in Figures 11 and 12 and show that the gender gap decreases, as the index for attitudes increases, for all the 4 cohorts considered. These results imply that the impact of gender is lower (closer to zero) among students with high preference for mathematics. For example, consider students in Year 5 in 2014. At the $10^{\text {th }}$ percentile, the difference in attitudes towards maths between girls and boys is around $40 \%$ of a standard deviation, while the gap is zero for students in the $90^{\text {th }}$ percentile of the attitudes index. Interestingly, in year 10, the gender gap in attitudes is quite small (around -10 to $-20 \%$ of a standard deviation) for very low and very high percentiles of attitudes, while it widens (around $-40 \%$ of a standard deviation) in the middle of the index distribution.

\subsection{Estimates of the MIMIC}

In this section, we report the results of the estimation of the MIMIC model presented above. In the estimation results, we show both the standardized and unstandardized solutions. Both are meaningful. The unstandardized solution is achieved by setting a lambda parameter equal to 1 and it also reports the standard errors and significance level of the coefficients. The disadvantage of unstandardized solutions is that they are not easily interpretable, as they refer to changes in variables that have no clear and homogeneous measurement unit. The standardized solution overcomes this problem. Standardization is achieved by setting the variance of the latent variable equal to 1 , therefore standardized coefficients can be read as the standard deviation change in the dependent variable that follows one standard deviation change in the independent variable. 
Table 5 reports the gender gap in mathematical capability as a result of the estimation of the SEM model. Appendix B shows the estimation of the full SEM model. The gender gap in mathematical capability is rather similar to the gender gap in attitudes: being female is associated with a lower mathematical capability, ranging from $15 \%$ to $18 \%$ of a standard deviation. Indeed the results for the measurement model reported in Table B1 and B2 in Appendix B show that the latent construct mathematical capability is mainly reflected into the indicators of attitude towards mathematics. Liking studying maths has the highest factor loading for grade 5: a standard deviation change in the latent capability leads to an increase of over $80 \%$ of a standard deviation in this indicator. The standardised coefficients of the other attitude indicators range from $50 \%$ to over $70 \%$ of a standard deviation in year 5 , and from over $60 \%$ to over $80 \%$ in year 10 . Test scores have the lowest factor scores in all the years and grades: these are approximately 30\% in year 5 and $40 \%$ in year 10 .

The results of the structural model presented in Table B3 and B4 in Appendix B also suggest that the influence of gender on mathematical capability is the highest among all sociodemographic explanatory variables. Similarly to what has been found for the OLS and OLS fixed-effect models, the effect of gender is, for example, twice as high as the effect of ESCS.

\section{Table 5 - The gender gap (G-B) in mathematical capability: gender coefficient in SEM models.}

\begin{tabular}{lcccc}
\hline SEM & Year 5 2014 & Year 5 2015 & Year 10 2014 & Year 10 2015 \\
\hline Unstandardised & $-0.322^{* * *}$ & $-0.276^{* * *}$ & $-0.284^{* * *}$ & $-0.257^{* * *}$ \\
& $(0.015)$ & $(0.018)$ & $(0.013)$ & $(0.021)$ \\
Standardised & $-0.180^{* * *}$ & $-0.150^{* * *}$ & $-0.166^{* * *}$ & $-0.147^{* * *}$ \\
\hline $\mathbf{N}$ & 22,246 & 18,231 & 31,644 & 22,772
\end{tabular}

Note: Std errors are in brackets. * indicates that the underlying coefficient is significant at 5\% level, $* *$ at $1 \%$ and $* * * 0.1 \%$. All models include area of residence include maternal and paternal education, ESCS index (Socio-economic indicator). Models for year 10 include also the type of high school (Lyceum, Professional or Vocational)

In the SEM model, gender does not directly affect the single item for attitude towards mathematics and test scores, as the relationship between these variables is modelled to be mediated by the latent capability. Nevertheless, the indirect effects of being female on the single indicators of mathematical capability can easily be computed, this being equal to the product of the path from gender to the latent variable by the path from the latent variable to the indicator. Gender indirect effects are presented in 
Table 6 both in unstandardized and standardized form. These can be read as the gender gap (G-B) in the single indicators of the SEM model, confirming the higher impact of gender on variables of attitude rather than on the test scores.

Table 6 - The indirect effects of gender (i.e. being female) on the indicators of mathematical capability (unstandardized and standardised)

\begin{tabular}{|c|c|c|c|c|}
\hline Unstandardized & Year 52014 & Year 52015 & Year 102014 & Year 102015 \\
\hline \multirow[t]{2}{*}{ I like studying maths } & $-0.322 * * *$ & $-0.276^{* * *}$ & $-0.284 * * *$ & $-0.257 * * *$ \\
\hline & $(0.015)$ & $(0.018)$ & $(0.013)$ & $(0.021)$ \\
\hline \multirow[t]{2}{*}{ I learn lots of things in maths } & $-0.183 * * *$ & $-0.152 * * *$ & $-0.235 * * *$ & $-0.187 * * *$ \\
\hline & $(0.009)$ & $(0.010)$ & $(0.011)$ & $(0.015)$ \\
\hline \multirow[t]{2}{*}{ Maths is boring (reversed) } & $-0.260 * * *$ & $-0.244 * * *$ & $-0.251 * * *$ & $-0.227 * * *$ \\
\hline & $(0.012)$ & $(0.016)$ & $(0.011)$ & $(0.018)$ \\
\hline \multirow[t]{2}{*}{ I am usually good at maths } & $-0.237 * * *$ & $-0.159 * * *$ & & \\
\hline & $(0.012)$ & $(0.011)$ & & \\
\hline \multirow[t]{2}{*}{ I learn maths easily } & $-0.259 * * *$ & $-0.191 * * *$ & $-0.299 * * *$ & $-0.239 * * *$ \\
\hline & $(0.013)$ & $(0.013)$ & $(0.014)$ & $(0.020)$ \\
\hline \multirow{2}{*}{$\begin{array}{l}\text { Maths is harder for me than for } \\
\text { my classmates (reversed) }\end{array}$} & $-0.204 * * *$ & $-0.152 * * *$ & & \\
\hline & $(0.010)$ & $(0.011)$ & & \\
\hline \multirow{2}{*}{$\begin{array}{l}\text { I have always thought maths is } \\
\text { one of my strongest subjects }\end{array}$} & & & $-0.313 * * *$ & $-0.256^{* * *}$ \\
\hline & & & $(0.014)$ & $(0.021)$ \\
\hline \multirow[t]{2}{*}{ I understand the hardest topics } & & & $-0.292 * * *$ & $-0.226 * * *$ \\
\hline & & & $(0.013)$ & $(0.019)$ \\
\hline \multirow[t]{2}{*}{ Standardized maths test scores } & $-0.101 * * *$ & $-0.089 * * *$ & $-0.136 * * *$ & $-0.128 * * *$ \\
\hline & $(0.006)$ & $(0.007)$ & $(0.007)$ & $(0.012)$ \\
\hline Standardized & Year 52014 & Year 52015 & Year 102014 & Year 102015 \\
\hline I like studying maths & $-0.152 * * *$ & $-0.130 * * *$ & $-0.138 * * *$ & $-0.126^{* * *}$ \\
\hline I learn lots of things in maths & $-0.113^{* * *}$ & $-0.093 * * *$ & $-0.122 * * *$ & $-0.102 * * *$ \\
\hline Maths is boring (reversed) & $-0.130 * * *$ & $-0.116^{* * *}$ & $-0.114 * * *$ & $-0.108 * * *$ \\
\hline I am usually good at maths & $-0.137 * * *$ & $-0.100 * * *$ & & \\
\hline I learn maths easily & $-0.138 * * *$ & $-0.104 * * *$ & $-0.146 * * *$ & $-0.122 * * *$ \\
\hline
\end{tabular}


Maths is harder for me than for

my classmates (reversed)

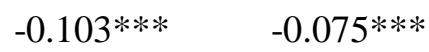

I have always thought maths is

one of my strongest subjects

I understand the hardest topics

$-0.144 * * * \quad-0.121 * * *$

Standardized maths test scores

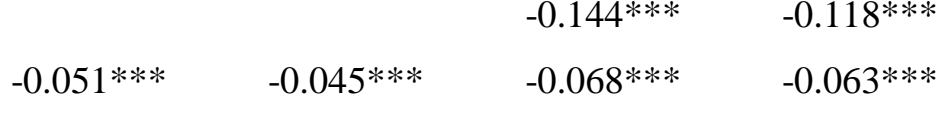

Note: Std errors are in brackets. $*$ indicates that the underlying coefficient is significant at $5 \%$ level, $* *$ at $1 \%$ and $* * * 0.1 \%$.

\section{Conclusions}

The gender gap in mathematics is particularly wide in Italy. Despite the growing concern about this problem, both at the European and at national level, there are not many policies to address it.

This paper contributes to the existing literature on the gender gap in mathematics by adding an analysis of the attitudes towards mathematics in a gender perspective. Attitudes towards mathematics are strongly correlated to test scores but the direction of causality (if test scores influence attitudes or viceversa) is not particularly interesting when trying to design policies. Much more important is to understand how the gender gap changes when considering both elements.

We use a Structural Equation Model, where we estimate a single indicator of mathematical capability including both tests scores and attitudes and we show that the gender gap is even wider in mathematical capability than in test scores alone. Therefore policies that tackle the gender gap should not only address test scores but also attitudes. In particular, our estimates for the measurement equation of the model show that the factor loadings for attitudes are higher in absolute value than the factor loadings on test scores, suggesting that tackling differences in attitudes could be more effective than tackling test scores alone. 


\section{References}

Aigner, D.J., Hsiao, C., Kapteyn, A., Wansbeek, T., 1984. Latent variable models in econometrics. In: Griliches, Z., Intriligator, M.D. (Eds.), Handbook in Econometrics, vol. 2. North Holland, Amsterdam, pp. 1323-1393.

Allport, G. W. (1935). Attitudes. In C. A. Murchinson (Ed.), A handbook of social psychology (pp. 798- 844). Worcester, MA: Clark University Press.

Angrist, J., E. Battistin, and D. Vuri (2015). In a Small Moment: Class Size and Moral Hazard in the Mezzogiorno. American Economic Journal: Applied Economics, vol 9(4), pages 216-249.

Attanasio O. P. (2015) The Determinants of Human Capital Formation during the Early Years of Life: Theory, Measurement, and Policies. Journal of the European Economic Association, 13(6) pp 949-997.

Bertoni, M., G. Brunello, and L. Rocco (2013). When the cat is near the mice won't play: the effect of external examiners in Italian schools. Journal of Public Economics 104, 65-77

Bentler, P.M., Weeks, D.G., 1980. Multivariate analysis with latent variables. In: Krishnaiah, P.R., Kanla, L.N. (Eds.), Handbook of Statistics. North Holland, Amsterdam, pp. 747-771.

Boaler, J. (2002a). The development of disciplinary relationships: Knowledge, practice and identity in mathematics classrooms. For the learning of mathematics 22(1), p. 42-47.

Contini D., Di Tommaso M.L., Mendolia S. (2017), “The gender gap in mathematics achievement: Evidence from Italian data.” Economics of Education Review, 58, pp 32-42.

Cornwell, C., Mustard, D. B., \& Van Parys, J. (2013). Noncognitive skills and the gender disparities in test scores and teacher assessments evidence from primary school. Journal Human Resources, 48(1), 236-264.

Cunha, F., Heckman, J. J., \& Schennach, S. M. (2010). Estimating the technology of cognitive and noncognitive skill formation. Econometrica, 78(3), 883-931.

Daskalogianni, K., \& Simpson, A. (2000). Towards a definition of attitude: The relationship between the affective and the cognitive in pre-university students. In T. Nakahara \& M. Koyama (Eds.), Proceedings of the 24th conference of the international group for the psychology of mathematics education (Vol. 3, pp. 217-224). Hiroshima, Japan: PME.

Di Martino, P., \& Zan, R. (2010). 'Me and maths': Towards a definition of attitude grounded on students’ narratives. Journal of Mathematics Teacher Education, 13(1), 27-48. 
Di Martino, P., \& Zan, R. (2010). Attitude towards mathematics: a bridge between beliefs and emotions. Mathematics Education (2011) 43:471-482 DOI 10.1007/s11858-011-0309-6.

Edwards, J., \& Bagozzi, R. (2000). On the Nature and Direction of Relationships Between Constructs and Measures. Psychological Methods, 5(2), 155-174.

Else-Quest, N. M., Hyde, J. S., \& Linn, M. C. (2010). Cross-national patterns of gender differences in mathematics: A meta-analysis. Psychological Bulletin, 136(1), 103-127. doi:10.1037/a0018053

European Commission 2006, Women in Science and Technology- the Business Perspective, Luxembourg: Office for Official Publication of the European Communities

European Commission 2012, Enhancing excellence, gender equality and efficiency in research and innovation, Luxembourg: Office for Official Publication of the European Communities

European Commission 2015. Science is a girls’ thing, Newsletter Nov. 2015 http://science-girlthing.eu/newsletters/november-2015.html

Fryer, Roland G., and Steven D. Levitt. (2010) "An Empirical Analysis of the Gender Gap in Mathematics." American Economic Journal: Applied Economics, 2(2): 210-40.

Gutman, L. M., \& Schoon, I. (2013). Non-cognitive skills: Evidence and intervention. London: Education Endowment Foundation.

Haladyna, T., Shaughnessy, J., \& Shaughnessy, M. (1983). A causal analysis of attitude toward mathematics. Journal for Research in Mathematics Education, 14(1), 19-29.

Hart, L. (1989). Describing the affective domain: Saying what we mean. In D. Mc Leod \& V. M. Adams (Eds.), Affect and mathematical problem solving (pp. 37-45). New York: Springer.

Heckman, J. J. (2008). Schools, skills, and synapses. Economic Inquiry, 46(3), 289-324.

Heckman, J. J. \& T. Kautz (2012). Hard evidence on soft skills. Labour Economics, 19, 451-464.

Heckman, J. J. \& T. Kautz (2014). Fostering and measuring skills interventions that improve character and cognition. In J. J. Heckman, J. E. Humphries, and T. Kautz (Eds.), The GED Myth: Education, Achievement Tests, and the Role of Character in American Life, Chapter 9. Chicago, IL: University of Chicago Press.

Heckman, J. J., \& Mosso, S. 2014. The economics of human development and social mobility. In NBER working paper no. 19925.

Larsen, J. (2013). Attitude in Mathematics: a thematic literature review. British Columbia, BC: Simon Fraser University. 
Leder, G. (1985). Measurement of attitude to mathematics. For the Learning of Mathematics, 34(5), $18-21$.

Lubienski, S., Robinson, J., Crane, C., Ganley, C. (2013) Girls' and Boys' Mathematics Achievement, Affect, and Experiences: Findings from ECLS-K. Journal for Research in Mathematics Education, 44, 634-645.

Lucifora, C.Tonello M. (2015), Cheating and social interactions. Evidence from a randomized experiment in a national evaluation program, Journal of Economic Behavior \& Organization, 115, 45-66.

McLeod, D. (1992). Research on affect in mathematics education: A reconceptualization. In D. Grows (Ed.), Handbook of research on mathematics teaching and learning (pp. 575-596). New York: McMillan.

Mullis, I. V. S., Martin, M. O., Foy, P., \& Hooper, M. (2016). TIMSS 2015 International Results in Mathematics. Retrieved from Boston College, TIMSS \& PIRLS International Study Center

Mullis, I.V.S., Martin, M.O., \& Foy, P. (with Olson, J.F., Preuschoff, C., Erberber, E., Arora, A., \& Galia, J.). (2008). Chestnut Hill, MA: TIMSS \& PIRLS International Study Center, Boston College.

National Academy of Science (2007) Beyond Bias and Barriers: Fulfilling the Potential of Women in Academic Science and Engineering (2007)

Neale, D. (1969). The role of attitudes in learning mathematics. The Arithmetic Teacher, Dec., 631641.

Newcombe, N.S., Levine, S.C. \& Mix, K. S. (2015).Thinking about quantity: The intertwined development of spatial and numerical cognition. WIREs in Cognitive Science, 6, 491-505.

Nussbaum, M. (2003). Capabilities as fundamental entitlements: Sen and social justice. Feminist Economics, 9(2\&3), 33-59.

OECD. (2015). The ABC of Gender Equality in Education: Aptitude, Behaviour, Confidence. PISA, OECD Publishing.

OECD (2016), PISA 2015 Results (Volume I): Excellence and Equity in Education, OECD Publishing, Paris.

Paccagnella M., Sestito P. (2014), School Cheating and Social Capital, Education Economics, 22(4), 
$367-388$

Ruffell, M., Mason, J., \& Allen, B. (1998). Studying attitude to mathematics. Educational Studies in Mathematics, 35(1), 1-18.

Sen, A. K. (1985). Commodities and capabilities. Amsterdam: North Holland.

Sen, A. K. (1999). Development as freedom. Oxford: Oxford University Press.

Sen, A. K. (2009). The idea of justice. London: Allen Lane.

Sikora, J., \& Pokropek, A. (2012). Gender segregation of adolescent science career plans in 50 countries. Science Education, 96(2), 234-264.

Zohar, A., \& Sela, D. (2003). Her physics, his physics: gender issues in Israeli advanced placement physics classes.” International Journal of Science Education, 25(2), 245-268. 


\section{Figures}

Figure 1 - Average standardised test scores by attitudes and gender. Year 5, 2014
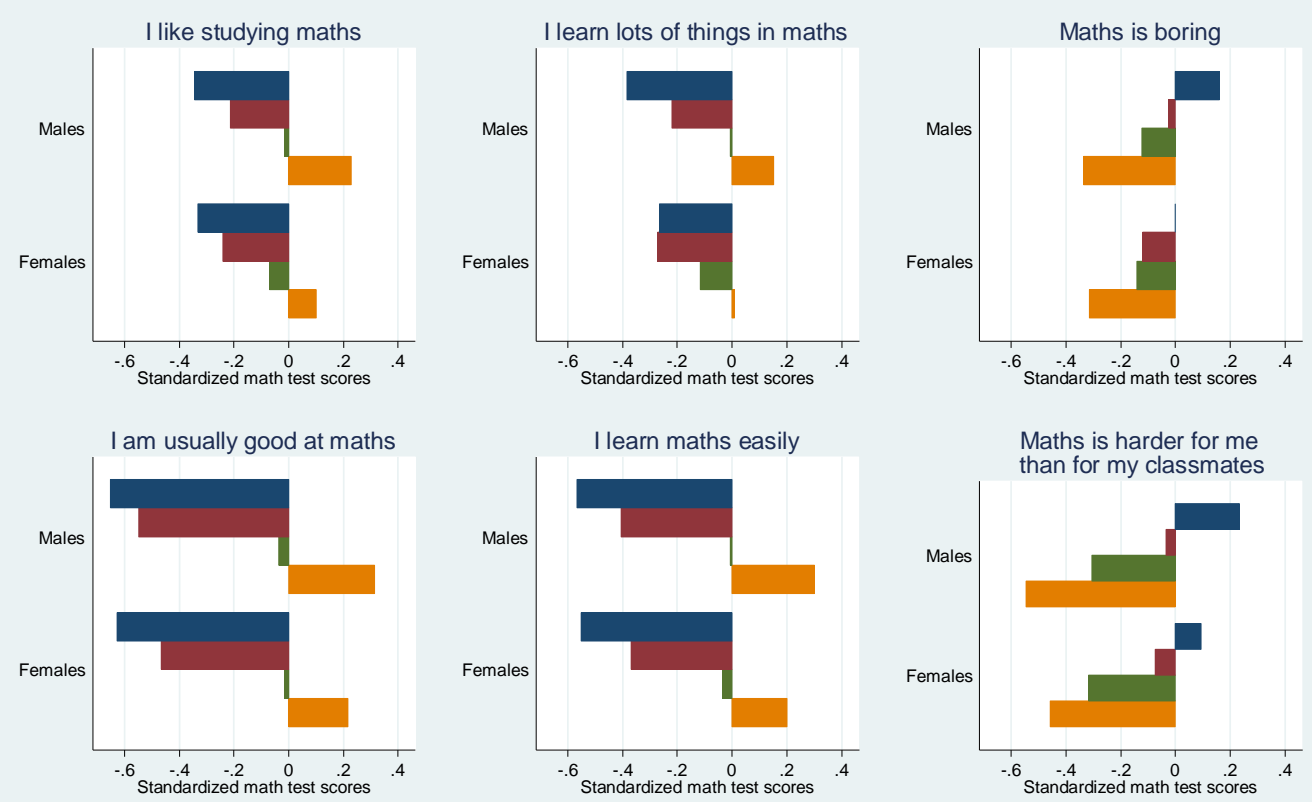

\begin{tabular}{|l|l|}
\hline Strongly disagree & Disagree \\
Agree & Strongly agree \\
\hline
\end{tabular}

Figure 2 - Average standardised test scores by attitudes and gender. Year 5, 2015
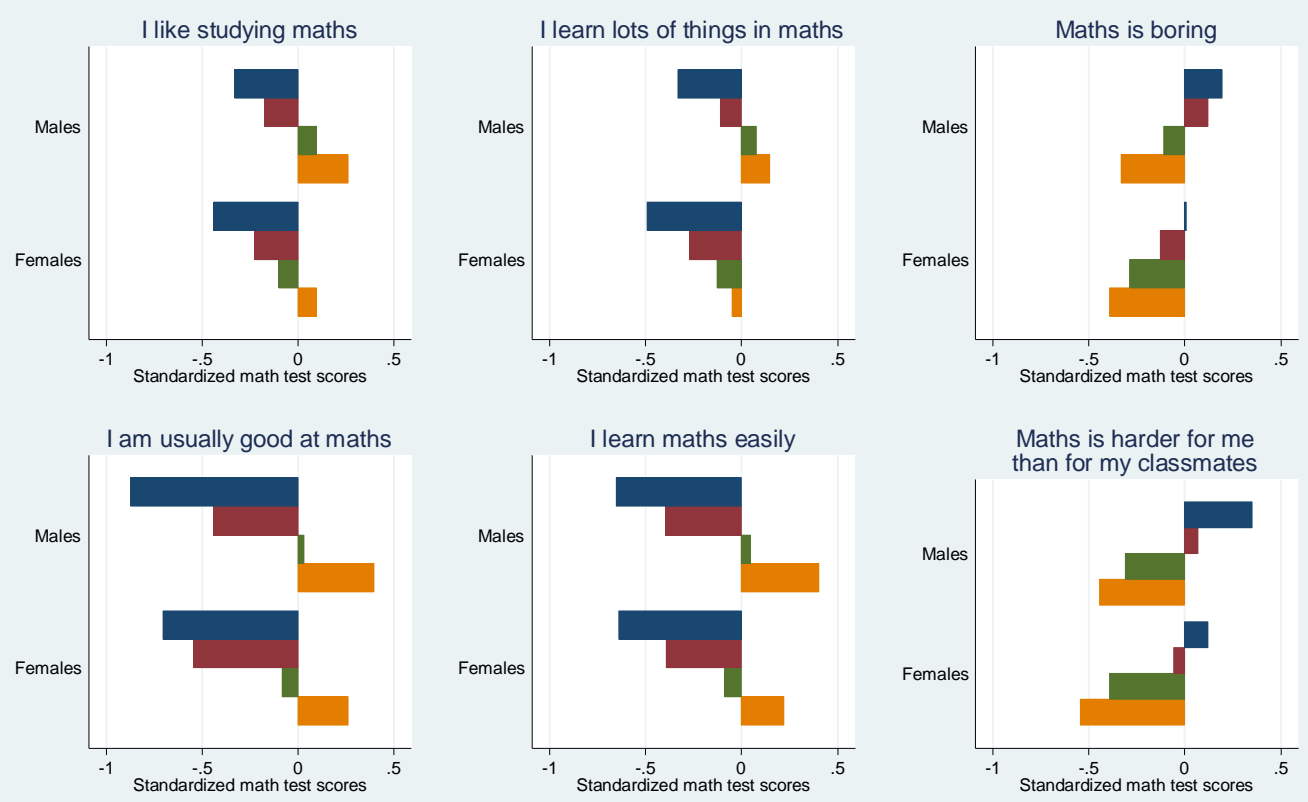

Strongly disagree

Disagree

Agree

Strongly agree 
Figure 3 - Average standardised test scores by attitudes and gender. Year 10, 2014

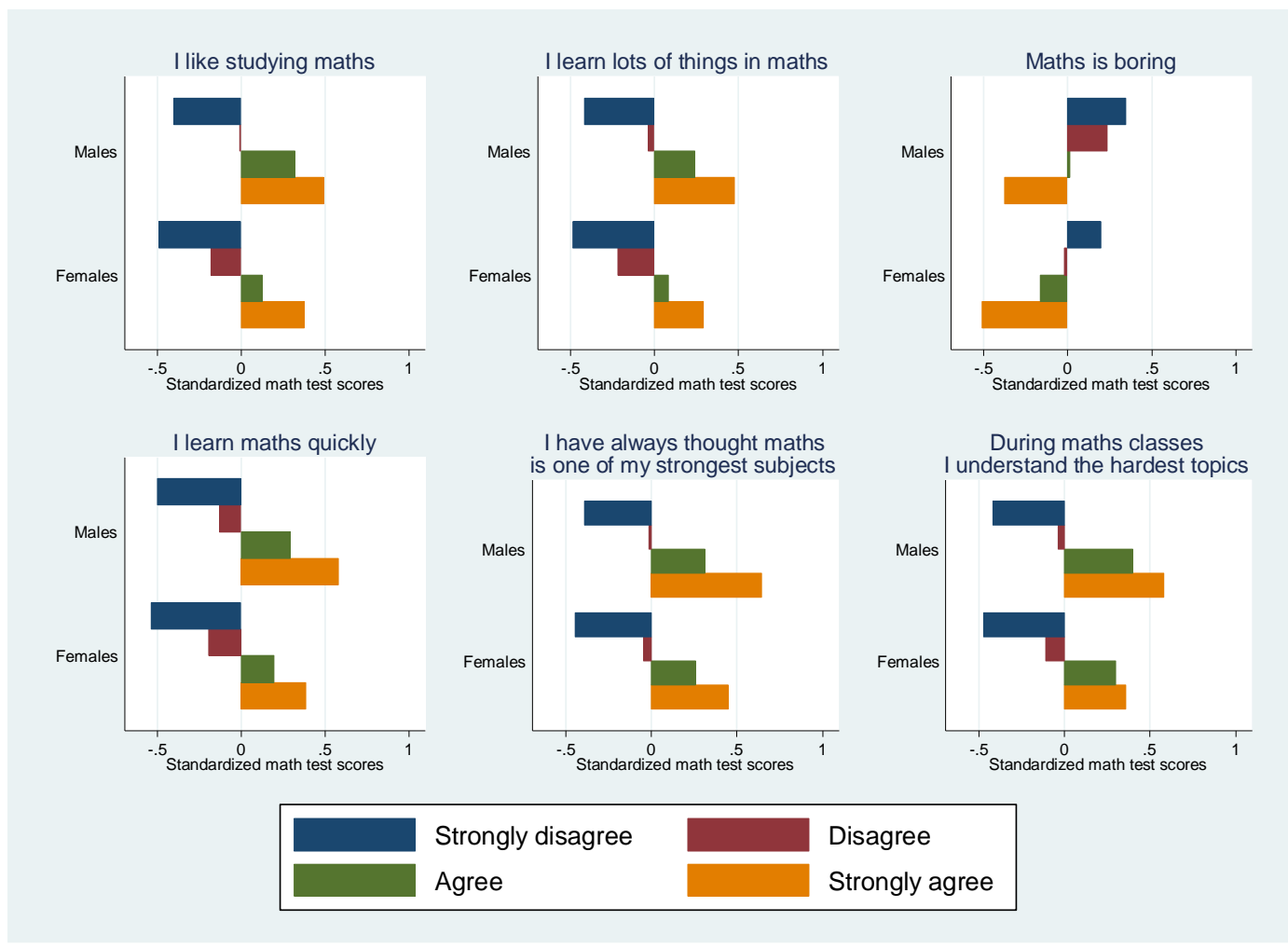

Figure 4- Average standardised test scores by attitudes and gender. Year 10, 2015

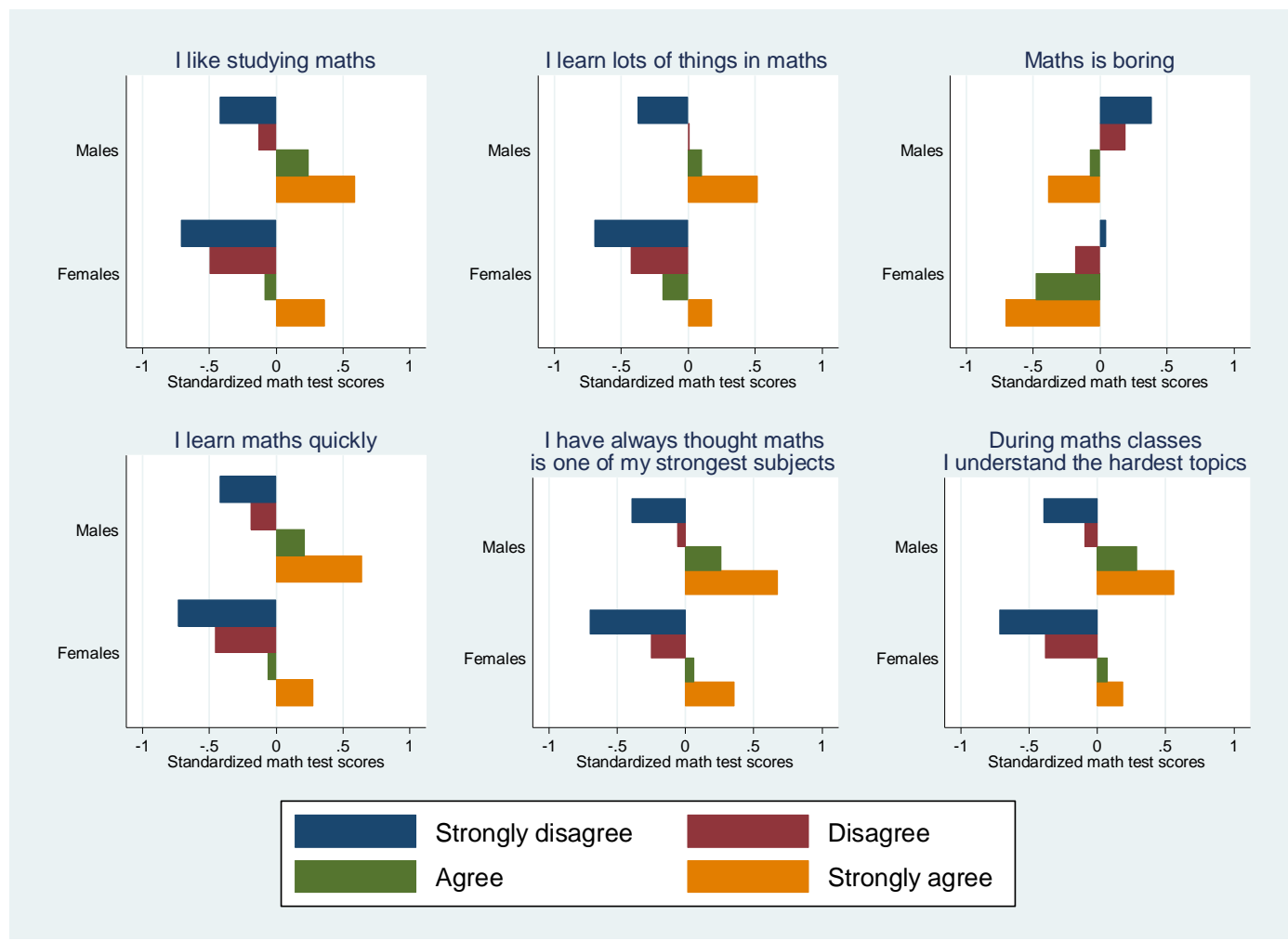


Figure 5 - Attitudes towards maths by gender - Year 5, 2014

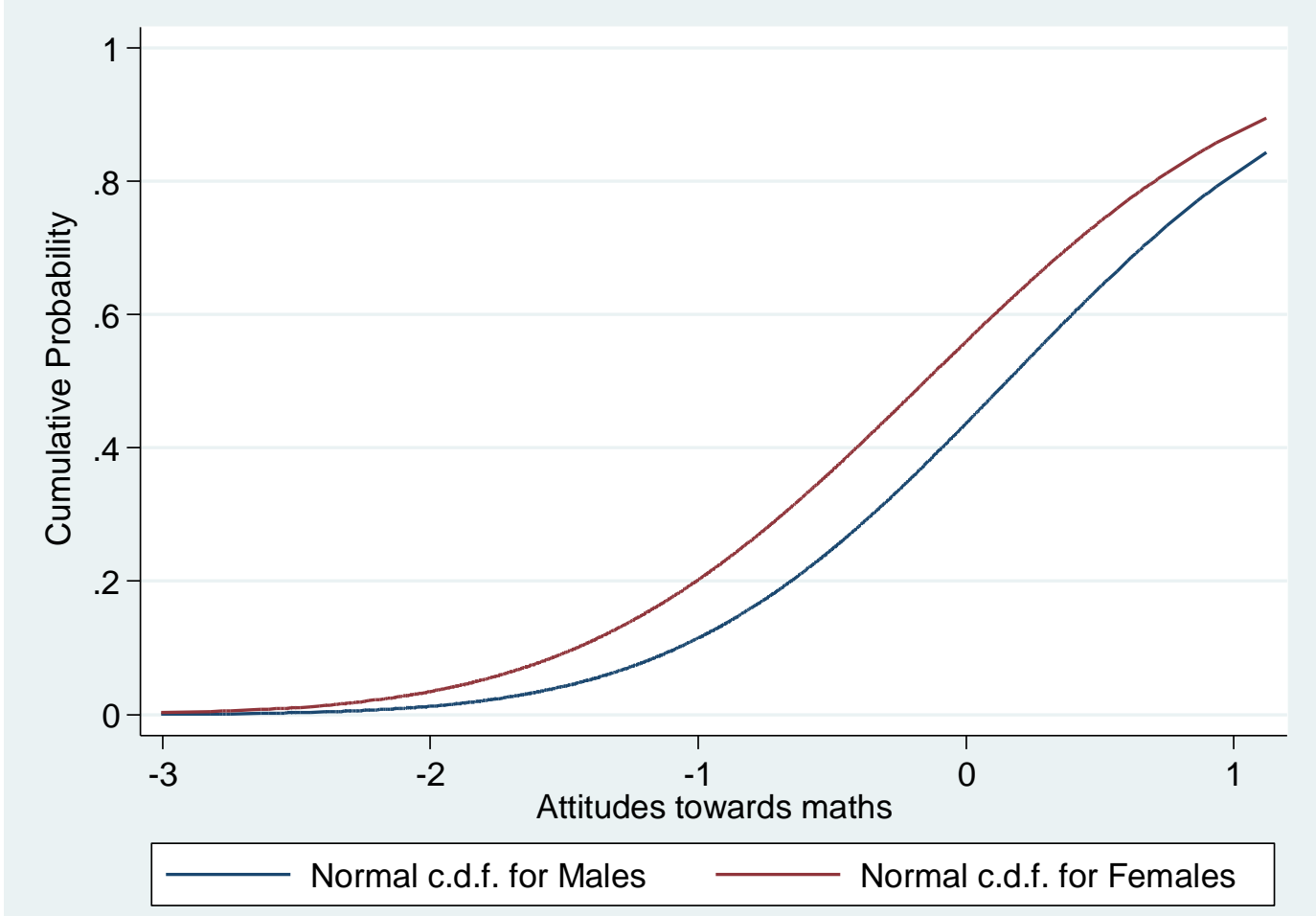

Figure 6 - Attitudes towards maths by gender - Year 5, 2015

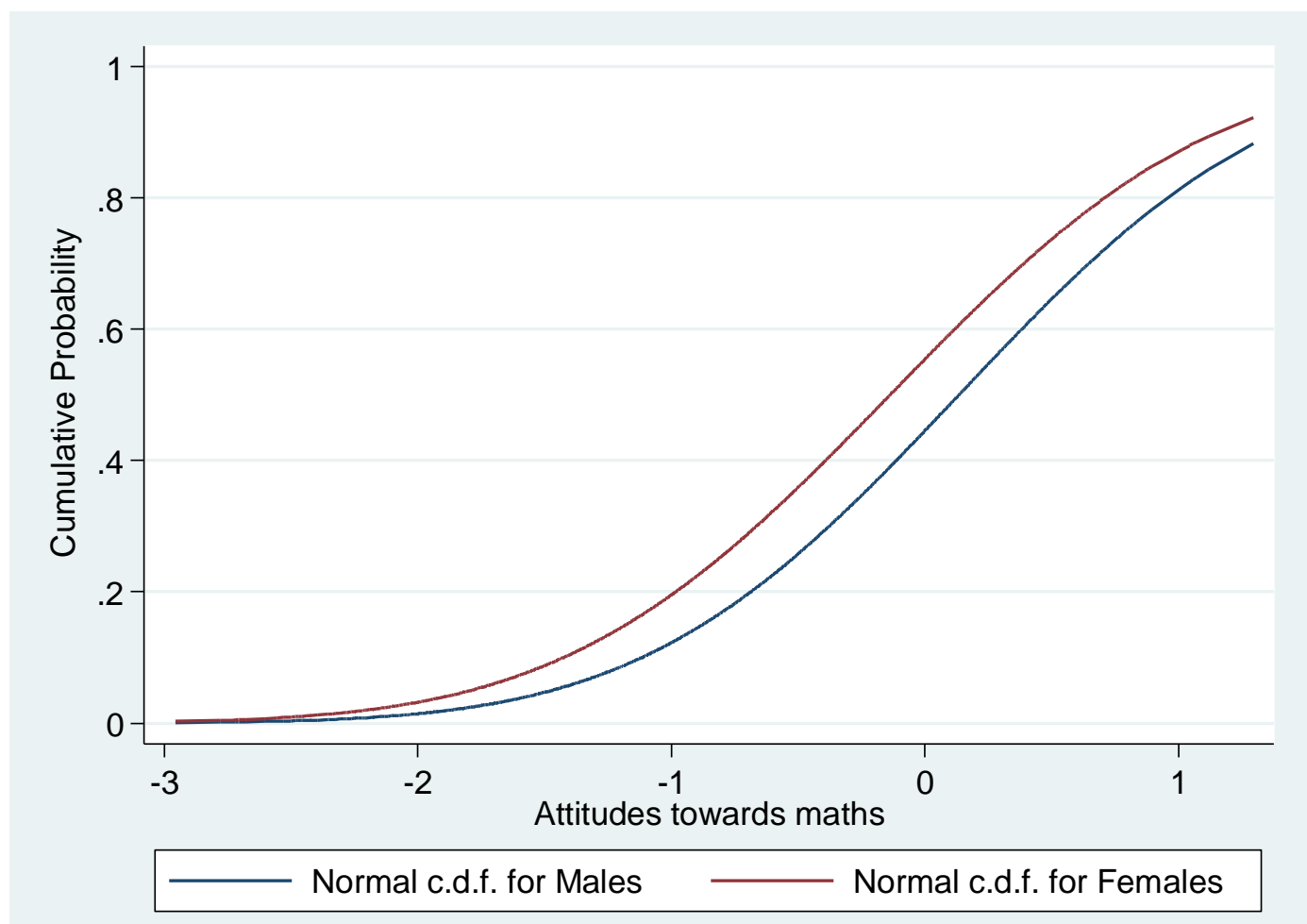


Figure 7- Attitudes towards maths by gender - Year 10, 2014

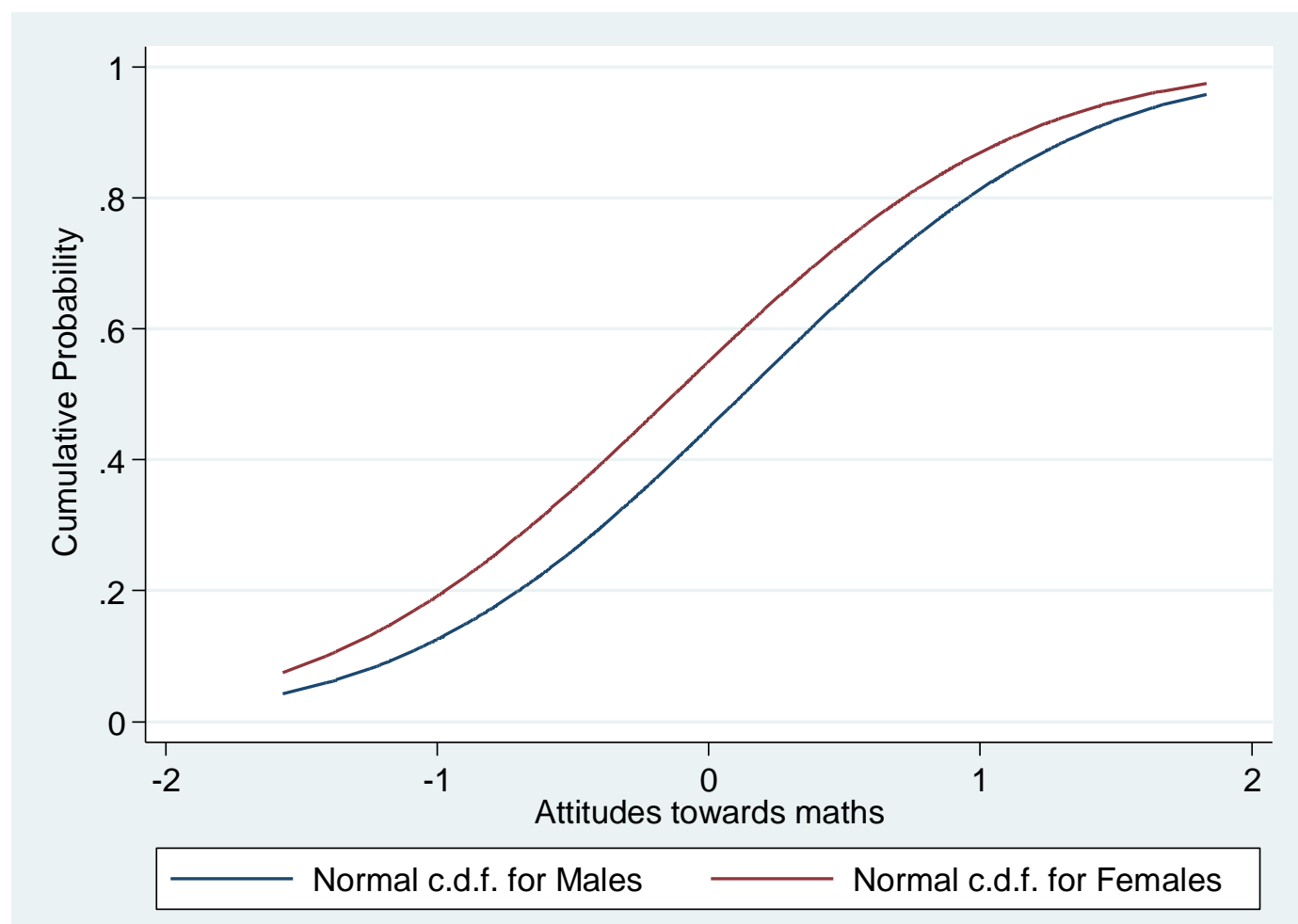

Figure 8- Attitudes towards maths by gender - Year 10, 2015

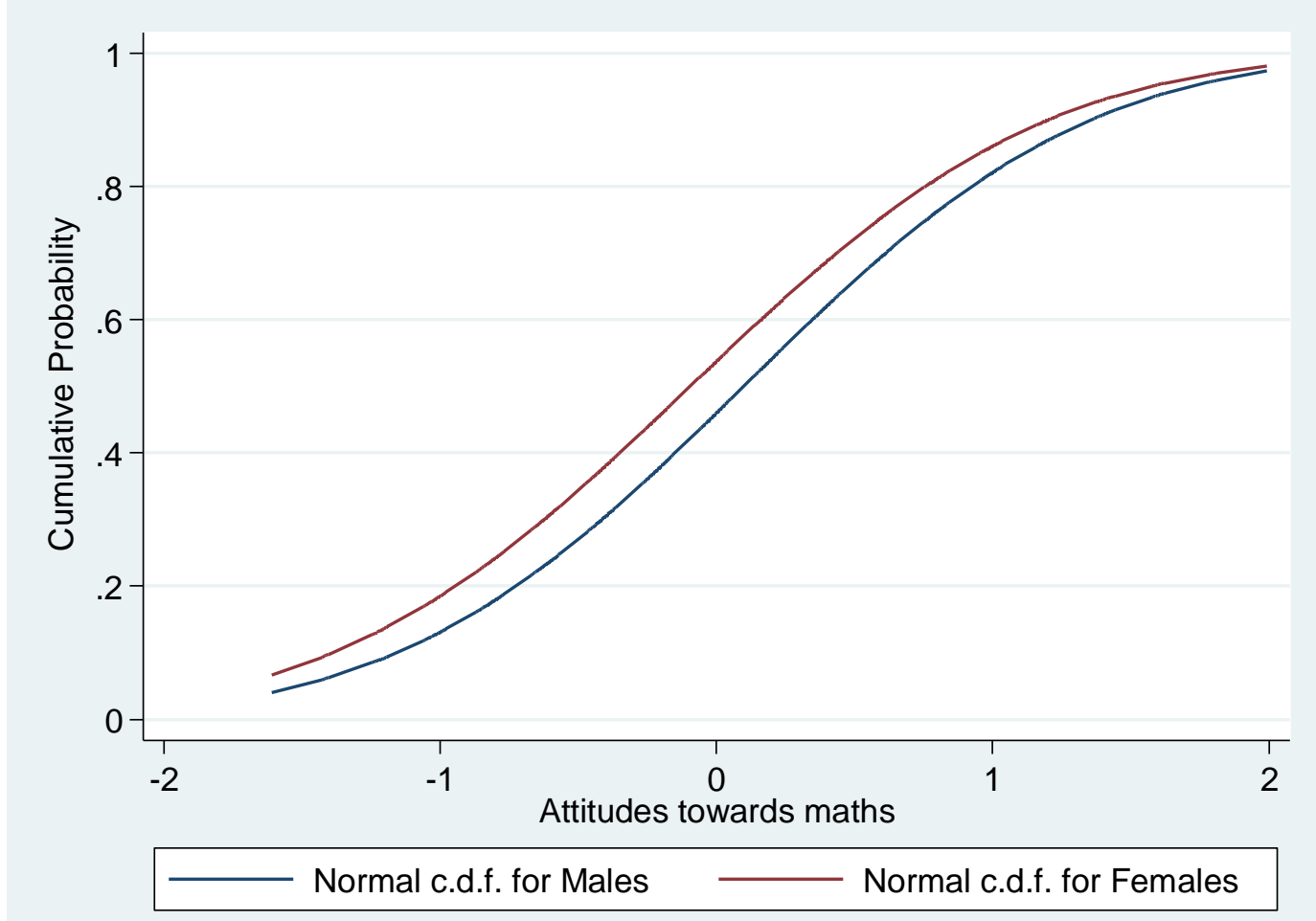


Fig.9 - Standardised test scores in mathematics and an index of attitudes towards mathematics - Year 5

2014

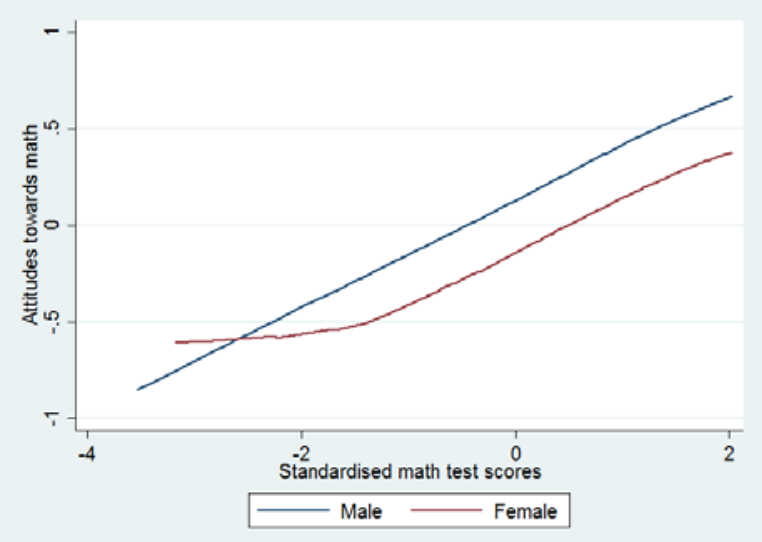

2015

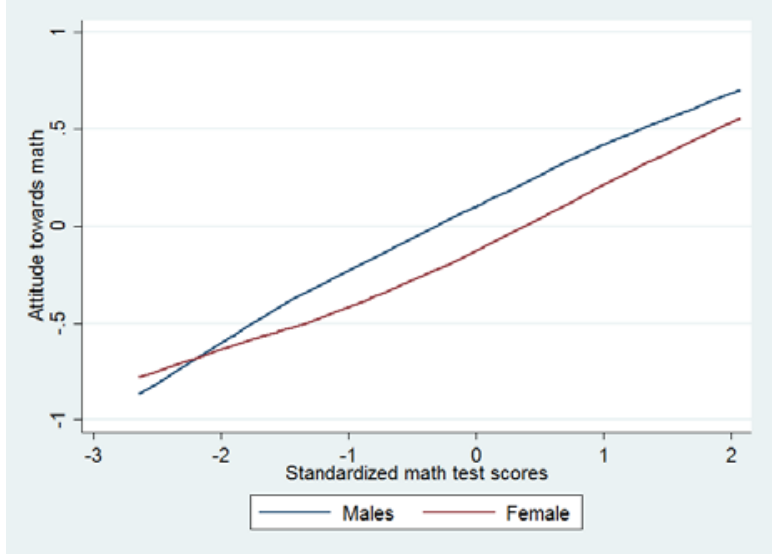

Fig.10 - Standardised test scores in mathematics and an index of attitudes towards mathematics - Year 10

2014

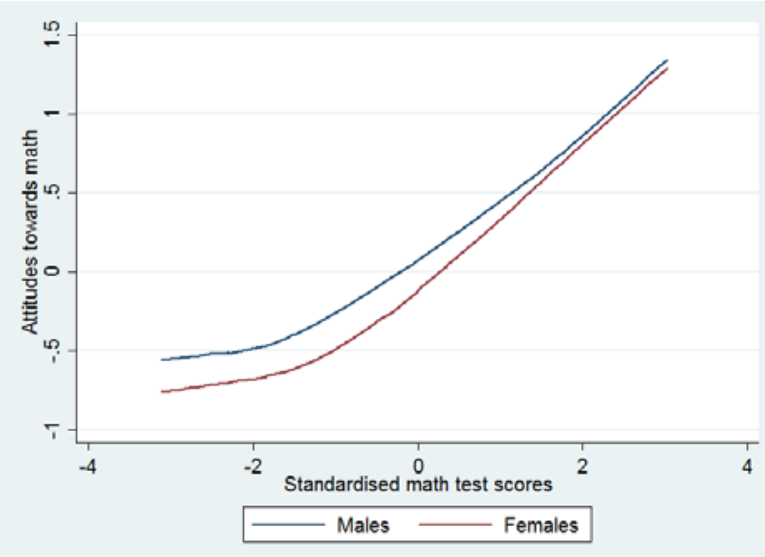

2015

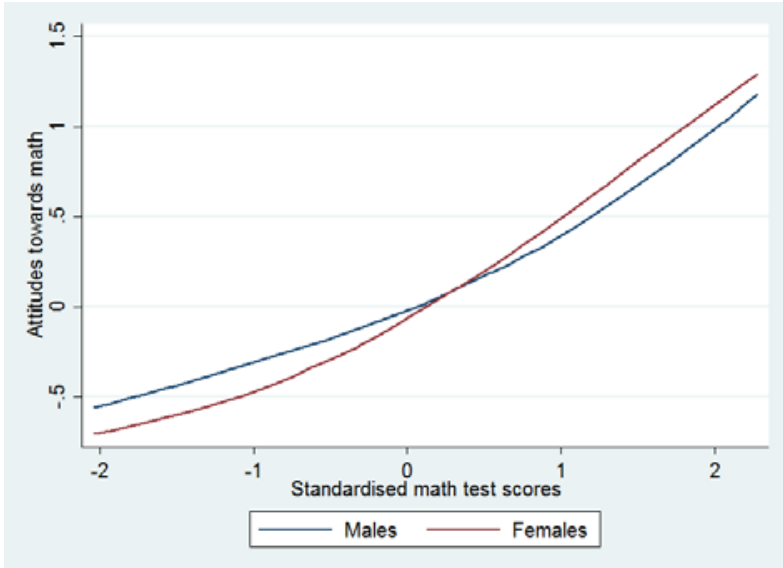


Fig. 11 - Results from quantile regression: impact of gender on attitudes towards maths (Year 5)
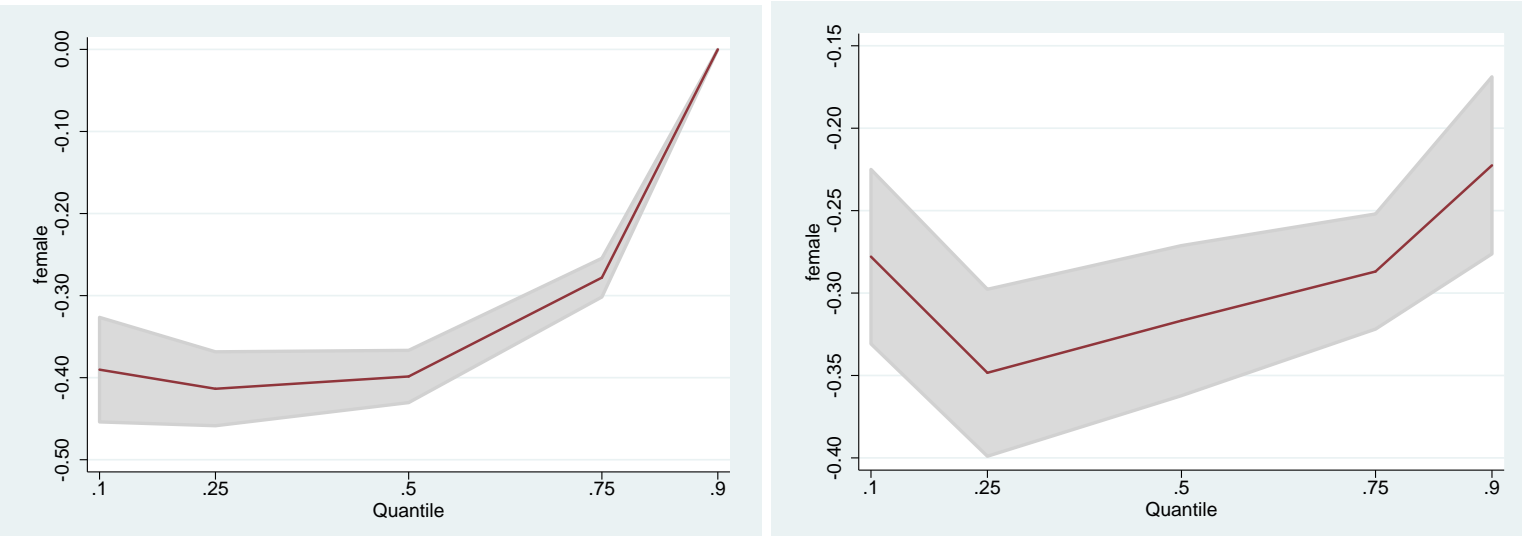

Fig. 12 - Results from quantile regression: impact of gender on attitudes towards maths (Year 10) 2014 2015
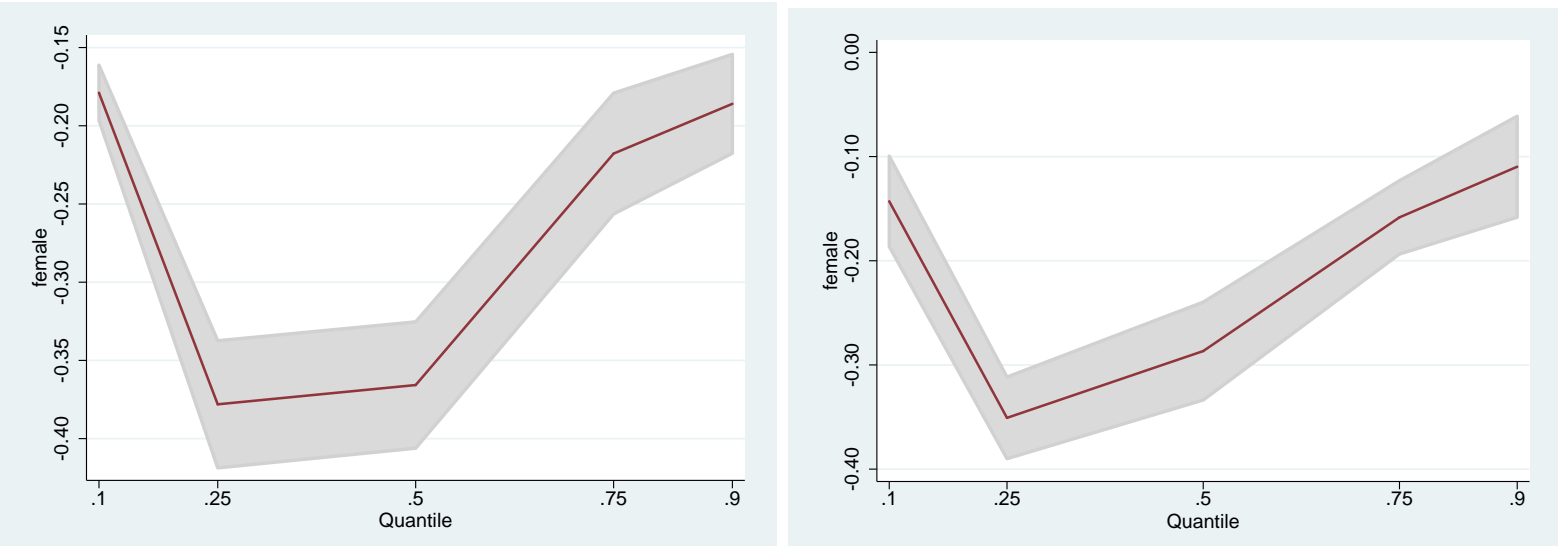
Appendix A

Table A1-Attitudes towards maths for year 5 students

\begin{tabular}{|c|c|c|c|c|c|c|c|c|}
\hline \multicolumn{5}{|c|}{ Year 52014} & \multicolumn{4}{|c|}{ Year 52015} \\
\hline & $\begin{array}{r}\text { (\% all } \\
\text { sample) }\end{array}$ & $\begin{array}{r}\text { Gender } \\
\text { gap (F-M) }\end{array}$ & \% Girls & \% Boys & $\begin{array}{r}\text { (\% all } \\
\text { sample) }\end{array}$ & $\begin{array}{r}\text { Gender } \\
\text { gap (F-M) }\end{array}$ & \% Girls & \% Boys \\
\hline \multicolumn{9}{|c|}{ I am usually good at maths } \\
\hline $\begin{array}{l}\text { Strongly } \\
\text { disagree }\end{array}$ & 5.84 & 3.17 & 7.44 & 4.27 & 4.50 & 1.57 & 5.30 & 3.73 \\
\hline Disagree & 14.07 & 6.83 & 17.51 & 10.68 & 13.14 & 6.21 & 16.32 & 10.11 \\
\hline Agree & 41.47 & 8.35 & 45.68 & 37.33 & 47.62 & 6.17 & 50.77 & 44.60 \\
\hline $\begin{array}{l}\text { Strongly } \\
\text { agree }\end{array}$ & 38.03 & -18.39 & 28.76 & 47.15 & 28.54 & -13.52 & 21.63 & 35.15 \\
\hline \multicolumn{9}{|c|}{ I learn maths easily } \\
\hline $\begin{array}{l}\text { Strongly } \\
\text { disagree }\end{array}$ & 7.80 & 2.90 & 9.26 & 6.36 & 7.51 & 3.52 & 9.31 & 5.79 \\
\hline Disagree & 16.45 & 6.46 & 19.71 & 13.25 & 16.55 & 6.29 & 19.76 & 13.47 \\
\hline Agree & 35.71 & 5.39 & 38.42 & 33.03 & 37.42 & 2.62 & 38.76 & 36.14 \\
\hline $\begin{array}{l}\text { Strongly } \\
\text { agree }\end{array}$ & 39.27 & -14.71 & 31.86 & 46.57 & 32.18 & -11.69 & 26.20 & 37.89 \\
\hline \multicolumn{9}{|c|}{ Maths is harder for me than for most of my class mates } \\
\hline $\begin{array}{l}\text { Strongly } \\
\text { disagree }\end{array}$ & 51.47 & -11.28 & 45.79 & 57.07 & 39.55 & -7.80 & 35.56 & 43.36 \\
\hline Disagree & 25.02 & 4.90 & 27.49 & 22.59 & 26.57 & 2.50 & 27.85 & 25.35 \\
\hline Agree & 14.10 & 4.00 & 16.12 & 12.12 & 17.88 & 3.51 & 19.68 & 16.17 \\
\hline $\begin{array}{l}\text { Strongly } \\
\text { agree }\end{array}$ & 8.78 & 2.47 & 10.02 & 7.55 & 9.49 & 2.38 & 10.71 & 8.33 \\
\hline \multicolumn{9}{|c|}{ I like studying maths } \\
\hline $\begin{array}{l}\text { Strongly } \\
\text { disagree }\end{array}$ & 12.60 & 4.81 & 15.02 & 10.21 & 13.47 & 4.08 & 15.56 & 11.48 \\
\hline Disagree & 14.19 & 5.73 & 17.08 & 11.35 & 15.85 & 5.79 & 18.81 & 13.02 \\
\hline Agree & 27.19 & 5.18 & 29.81 & 24.63 & 28.47 & 3.94 & 30.48 & 26.54 \\
\hline $\begin{array}{l}\text { Strongly } \\
\text { agree }\end{array}$ & 45.21 & -15.36 & 37.47 & 52.83 & 36.13 & -13.24 & 29.36 & 42.60 \\
\hline Missing & 0.81 & & 0.63 & 0.98 & 6.08 & -0.57 & 5.79 & 6.36 \\
\hline \multicolumn{9}{|c|}{ I learn lots of things in maths } \\
\hline $\begin{array}{l}\text { Strongly } \\
\text { disagree }\end{array}$ & 3.83 & 0.08 & 3.87 & 3.79 & 3.95 & -0.47 & 3.71 & 4.18 \\
\hline Disagree & 9.39 & 1.43 & 10.11 & 8.68 & 9.28 & 1.28 & 9.93 & 8.65 \\
\hline Agree & 32.66 & 4.94 & 35.15 & 30.21 & 33.81 & 3.51 & 35.61 & 32.10 \\
\hline $\begin{array}{l}\text { Strongly } \\
\text { agree }\end{array}$ & 53.41 & -6.22 & 50.27 & 56.49 & 46.64 & -3.81 & 44.69 & 48.50 \\
\hline \multicolumn{9}{|c|}{ Maths is boring } \\
\hline $\begin{array}{l}\text { Strongly } \\
\text { disagree }\end{array}$ & 57.78 & -7.47 & 54.02 & 61.49 & 48.72 & -7.63 & 44.82 & 52.45 \\
\hline Disagree & 22.41 & 4.58 & 24.72 & 20.14 & 21.78 & 4.57 & 24.12 & 19.55 \\
\hline Agree & 9.27 & 1.71 & 10.13 & 8.42 & 11.89 & 2.89 & 13.37 & 10.48 \\
\hline $\begin{array}{l}\text { Strongly } \\
\text { agree }\end{array}$ & 9.88 & 1.46 & 10.62 & 9.16 & 11.22 & 0.78 & 11.62 & 10.84 \\
\hline
\end{tabular}


Table A2- Attitudes towards maths for year 10 students

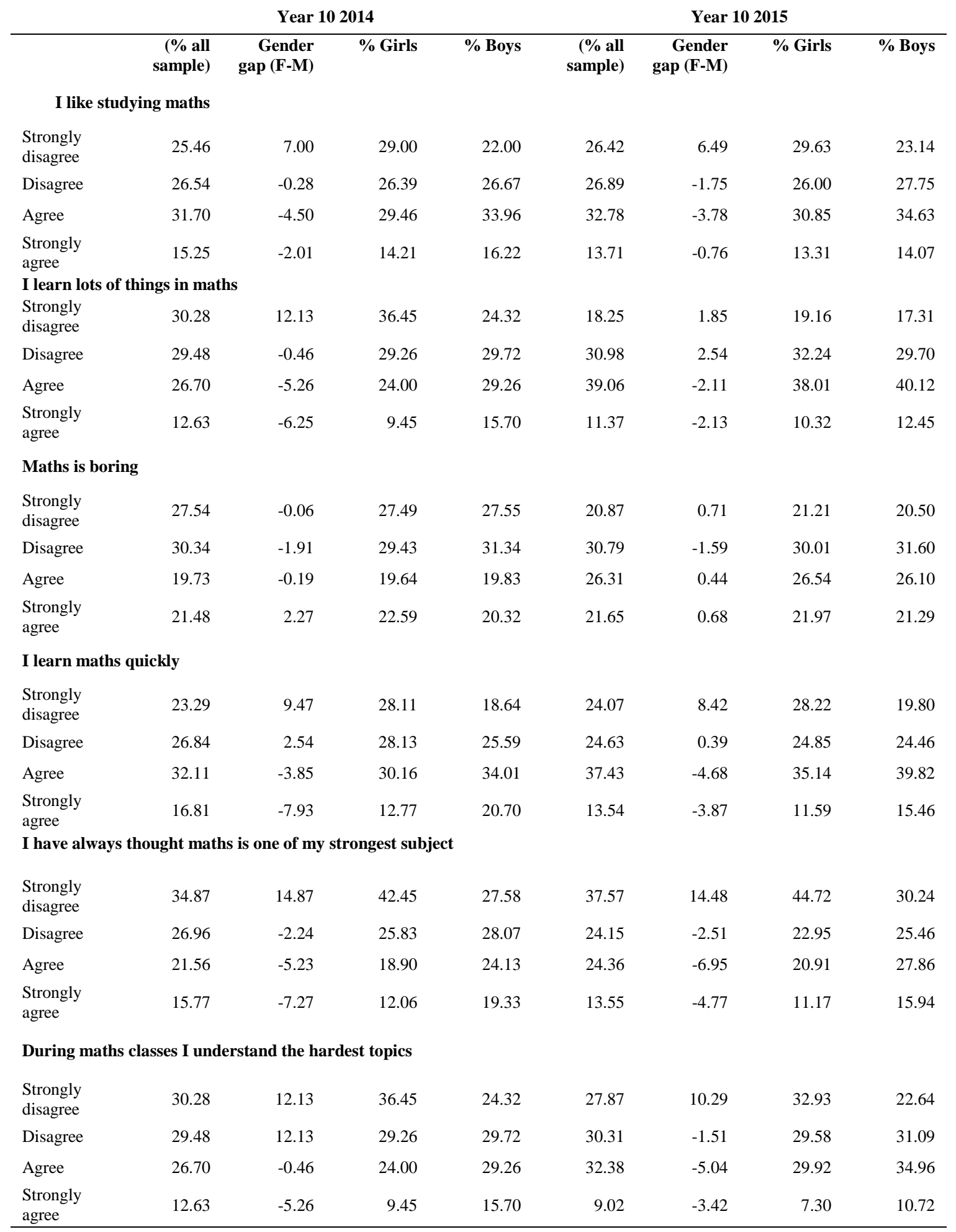


Table A3 - Factor Analysis. Maths attitudes

\begin{tabular}{lll}
\hline Factor & Eigenvalues & Variables \\
Year 5 -2014 & 0.8057 & I am usually good at maths \\
0.8163 & I learn maths easily \\
0.6619 & Maths is harder for me than \\
& for most of my class mates \\
0.8660 & I like studying maths \\
0.7089 & I learn lots of things in maths \\
0.7886 & Maths is boring
\end{tabular}

Year 5-2015

0.7596

0.7850

0.6086

0.8587

0.6907

0.7954

Year $10-2014$

0.8863

0.8157

0.7701

0.8802

0.8753

0.8717

Year $10-2015$

0.8874

0.7565

0.7976

0.8567

0.8473

0.8370
I am usually good at maths I learn maths easily Maths is harder for me than for most of my class mates I like studying maths I learn lots of things in maths Maths is boring

I like studying maths I learn lots of things in maths Maths is boring I learn maths quickly I have always thought maths is one of my strongest subject During maths classes I understand the hardest topics

I like studying maths I learn lots of things in maths Maths is boring I learn maths quickly I have always thought maths is one of my strongest subject During maths classes I understand the hardest topics 
Table A4: Descriptive statistics of the independent variables used in the estimation

\begin{tabular}{|c|c|c|c|c|}
\hline \multicolumn{5}{|l|}{ Gender } \\
\hline Male & 50.40 & 51.13 & 51.09 & 50.33 \\
\hline Female & 49.60 & 48.87 & 48.91 & 49.67 \\
\hline \multicolumn{5}{|l|}{ ESCS index } \\
\hline Mean & 0.12 & 0.21 & 0.024 & 0.075 \\
\hline Standard deviation & $(0.99)$ & $(0.92)$ & $(0.97)$ & $(0.95$ \\
\hline \multicolumn{5}{|l|}{ Area of residence } \\
\hline North-West & 16.30 & 20.20 & 19.05 & 27.06 \\
\hline North-East & 19.02 & 22.8 & 21.01 & 29.77 \\
\hline Centre & 17.80 & 20.26 & 17.24 & 21.65 \\
\hline South & 25.64 & 22.39 & 24.91 & 13.32 \\
\hline Islands & 21.23 & 14.35 & 17.78 & 8.19 \\
\hline \multicolumn{5}{|l|}{ Maternal education } \\
\hline Degree & 15.84 & 18.55 & 20.97 & 23.51 \\
\hline High school & 33.74 & 35.77 & 32.57 & 33.78 \\
\hline Middle school & 31.52 & 30.66 & 36.83 & 31.67 \\
\hline Missing & 18.88 & 15.02 & 9.71 & 11.04 \\
\hline \multicolumn{5}{|l|}{ Paternal education } \\
\hline Degree & 11.92 & 14.40 & 19.19 & 20.89 \\
\hline High school & 29.71 & 31.75 & 30.05 & 29.63 \\
\hline Middle school & 38.38 & 37.67 & 38.68 & 35.26 \\
\hline Missing & 19.97 & 16.17 & 12.06 & 14.21 \\
\hline \multicolumn{5}{|l|}{ Maternal occupation } \\
\hline Professional & 9.00 & 10.85 & 13.55 & 15.78 \\
\hline Self-employed (small business) & 5.96 & 6.93 & 9.00 & 9.64 \\
\hline Teacher or employee & 22.67 & 25.24 & 18.84 & 20.84 \\
\hline Manual worker & 9.59 & 10.67 & 16.30 & 17.93 \\
\hline Out of the labour force & 32.06 & 30.28 & 37.23 & 28.32 \\
\hline Missing & 20.71 & 16.00 & 5.06 & 7.47 \\
\hline \multicolumn{5}{|l|}{ Paternal occupation } \\
\hline Professional & 17.82 & 20.62 & 28.38 & 27.71 \\
\hline Self-employed (small business) & 15.81 & 17.25 & 20.00 & 19.94 \\
\hline Teacher or employee & 17.08 & 18.11 & 13.45 & 13.61 \\
\hline Manual worker & 21.15 & 21.48 & 23.98 & 23.43 \\
\hline Out of the labour force & 4.38 & 4.98 & 7.00 & 5.85 \\
\hline Missing & 23.75 & 17.54 & 7.19 & 9.42 \\
\hline
\end{tabular}


Table A5 - Effect of other independent variables on maths attitudes (linear model with fixed effects)

Year 5 2013-14 Year 5 2014-15 Year 10 2013-14 Year 10 2014-15

\begin{tabular}{|c|c|c|c|c|}
\hline Female & $\begin{array}{c}-0.327 * * * \\
(0.013)\end{array}$ & $\begin{array}{c}-0.277 * * * \\
(0.014)\end{array}$ & $\begin{array}{c}-0.144 * * * \\
(0.012)\end{array}$ & $\begin{array}{c}-0.071^{* * *} \\
(0.015)\end{array}$ \\
\hline Escs index & $\begin{array}{c}0.099 * * * \\
(0.011)\end{array}$ & $\begin{array}{c}0.104 * * * \\
(0.013)\end{array}$ & $\begin{array}{c}0.040 * * * \\
(0.008)\end{array}$ & $\begin{array}{c}0.042^{* * *} \\
(0.009)\end{array}$ \\
\hline \multicolumn{5}{|l|}{$\begin{array}{l}\text { Region of residence } \\
\text { (ref NW) }\end{array}$} \\
\hline $\mathrm{NE}$ & n.a. & n.a & n.a & n.a \\
\hline Centre & n.a & n.a & n.a & n.a \\
\hline South & n.a & n.a & n.a & n.a \\
\hline Islands & n.a & n.a & n.a & n.a \\
\hline \multicolumn{5}{|l|}{$\begin{array}{l}\text { Type of school } \\
\text { (ref Lyceum) }\end{array}$} \\
\hline Vocational high school & n.a & n.a & $\begin{array}{c}-0.420 * * * \\
(0.059)\end{array}$ & $\begin{array}{c}-0.166^{* *} \\
(0.069)\end{array}$ \\
\hline Technical high school & n.a & n.a & $\begin{array}{c}-0.136 * * * \\
(0.046)\end{array}$ & $\begin{array}{l}-0.003 \\
(0.049)\end{array}$ \\
\hline \multicolumn{5}{|l|}{$\begin{array}{l}\text { Maternal education } \\
\text { (ref University) }\end{array}$} \\
\hline Middle school & $\begin{array}{c}0.013 \\
(0.028)\end{array}$ & $\begin{array}{l}-0.037 \\
(0.030)\end{array}$ & $\begin{array}{c}0.001 \\
(0.019)\end{array}$ & $\begin{array}{c}0.013 \\
(0.023)\end{array}$ \\
\hline High school & $\begin{array}{l}0.043^{*} \\
(0.024)\end{array}$ & $\begin{array}{l}-0.001 \\
(0.024)\end{array}$ & $\begin{array}{c}0.022 \\
(0.017)\end{array}$ & $\begin{array}{c}0.023 \\
(0.019)\end{array}$ \\
\hline Missing & $\begin{array}{l}-0.010 \\
(0.044)\end{array}$ & $\begin{array}{l}-0.064 \\
(0.047)\end{array}$ & $\begin{array}{l}-0.007 \\
(0.028)\end{array}$ & $\begin{array}{c}0.002 \\
(0.032)\end{array}$ \\
\hline \multicolumn{5}{|l|}{$\begin{array}{l}\text { Paternal education } \\
\text { (ref University) }\end{array}$} \\
\hline Middle school & $\begin{array}{l}-0.022 \\
(0.029)\end{array}$ & $\begin{array}{l}-0.006 \\
(0.030)\end{array}$ & $\begin{array}{l}-0.031 \\
(0.020)\end{array}$ & $\begin{array}{c}-0.048 * * \\
(0.022)\end{array}$ \\
\hline High school & $\begin{array}{c}0.025 \\
(0.026)\end{array}$ & $\begin{array}{c}0.017 \\
(0.026)\end{array}$ & $\begin{array}{c}0.001 \\
(0.018)\end{array}$ & $\begin{array}{l}-0.008 \\
(0.020)\end{array}$ \\
\hline Missing & $\begin{array}{l}-0.019 \\
(0.043)\end{array}$ & $\begin{array}{l}-0.014 \\
(0.045)\end{array}$ & $\begin{array}{c}-0.061 * * \\
(0.026)\end{array}$ & $\begin{array}{c}-0.079 * * * \\
(0.029)\end{array}$ \\
\hline R squared & 0.038 & 0.031 & 0.040 & 0.005 \\
\hline $\mathrm{N}$ & 22,246 & 18,231 & 31,644 & 22,772 \\
\hline
\end{tabular}

Notes. Std errors are in brackets. * indicates that the underlying coefficient is significant at $5 \%$ level,

$* *$ at $1 \%$ and ${ }^{* * *} 0.1 \%$. Missing is a dummy variable equal 1 if the specific variable is missing; equal 0 otherwise. 


\section{Appendix B}

Table B1 - Results of SEM model - Measurement Model - Unstandardized Solution

\begin{tabular}{|c|c|c|c|c|}
\hline & $\begin{array}{c}(1) \\
\text { SEMV1315 }\end{array}$ & $\begin{array}{c}(2) \\
\text { SEMV1415 }\end{array}$ & $\begin{array}{c}\text { (3) } \\
\text { SEMX1314 }\end{array}$ & $\begin{array}{c}(4) \\
\text { SEMX1415 }\end{array}$ \\
\hline I like studying maths & $\begin{array}{c}1.000 \\
(.)\end{array}$ & $\begin{array}{c}1.000 \\
(.)\end{array}$ & $\begin{array}{c}1.000 \\
(.)\end{array}$ & $\begin{array}{c}1.000 \\
(.)\end{array}$ \\
\hline I learn lots of things in maths & $\begin{array}{c}0.568 * * * \\
(0.008)\end{array}$ & $\begin{array}{c}0.550 * * * \\
(0.008)\end{array}$ & $\begin{array}{c}0.829 * * * \\
(0.005)\end{array}$ & $\begin{array}{c}0.728^{* * *} \\
(0.008)\end{array}$ \\
\hline Maths is boring (reversed) & $\begin{array}{c}0.808^{* * *} \\
(0.008)\end{array}$ & $\begin{array}{c}0.886 * * * \\
(0.008)\end{array}$ & $\begin{array}{c}0.885^{* * *} \\
(0.006)\end{array}$ & $\begin{array}{c}0.885^{* * *} \\
(0.010)\end{array}$ \\
\hline I am usually good at maths & $\begin{array}{c}0.735^{* * *} \\
(0.009)\end{array}$ & $\begin{array}{c}0.577 * * * \\
(0.011)\end{array}$ & & \\
\hline I learn maths easily & $\begin{array}{c}0.804 * * * \\
(0.010)\end{array}$ & $\begin{array}{c}0.692 * * * \\
(0.012)\end{array}$ & $\begin{array}{c}1.052 * * * \\
(0.007)\end{array}$ & $\begin{array}{c}0.933 * * * \\
(0.012)\end{array}$ \\
\hline $\begin{array}{l}\text { Maths is harder for me than } \\
\text { for my classmates (reversed) }\end{array}$ & $\begin{array}{c}0.633^{* * *} \\
(0.011)\end{array}$ & $\begin{array}{c}0.550 * * * \\
(0.012)\end{array}$ & & \\
\hline $\begin{array}{l}\text { I have always thought maths } \\
\text { is one of my strongest subjects }\end{array}$ & & & $\begin{array}{c}1.102 * * * \\
(0.008)\end{array}$ & $\begin{array}{c}1.000 * * * \\
(0.012)\end{array}$ \\
\hline I understand the hardest topics & & & $\begin{array}{c}1.030 * * * \\
(0.007)\end{array}$ & $\begin{array}{c}0.881^{* * *} \\
(0.012)\end{array}$ \\
\hline Standardized maths test scores & $\begin{array}{c}0.315^{* * *} \\
(0.011) \\
\end{array}$ & $\begin{array}{c}0.324^{* * *} \\
(0.012) \\
\end{array}$ & $\begin{array}{c}0.478^{* * *} \\
(0.009) \\
\end{array}$ & $\begin{array}{c}0.499 * * * \\
(0.014) \\
\end{array}$ \\
\hline Observations & 22,246 & 18,231 & 31,594 & 22,772 \\
\hline
\end{tabular}

Standard errors in parentheses

*** $\mathrm{p}<0.01,{ }^{* *} \mathrm{p}<0.05$, * $\mathrm{p}<0.1$ 
Table B2 - Results of SEM model - Measurement Model - Standardized Solution

\begin{tabular}{|c|c|c|c|c|}
\hline & $\begin{array}{c}(1) \\
\text { SEMV1315 }\end{array}$ & $\begin{array}{c}(2) \\
\text { SEMV1415 }\end{array}$ & $\begin{array}{c}(3) \\
\text { SEMX1314 }\end{array}$ & $\begin{array}{c}(4) \\
\text { SEMX1415 }\end{array}$ \\
\hline I like studying maths & 0.849 & 0.865 & 0.833 & 0.859 \\
\hline I learn lots of things in maths & $0.631 * * *$ & $0.623 * * *$ & $0.738 * * *$ & $0.693 * * *$ \\
\hline Math is boring (reversed) & $0.726 * * *$ & $0.773 * * *$ & $0.688 * * *$ & $0.732 * * *$ \\
\hline I am usually good at maths & $0.764^{* * *}$ & $0.668 * * *$ & & \\
\hline I learn maths easily & $0.769 * * *$ & $0.695 * * *$ & $0.882 * * *$ & $0.827 * * *$ \\
\hline $\begin{array}{l}\text { Maths is harder for me than for my } \\
\text { classmates (reversed) }\end{array}$ & $0.575 * * *$ & $0.502 * * *$ & & \\
\hline $\begin{array}{l}\text { I have always thought maths is one of my } \\
\text { strongest subjects }\end{array}$ & & & $0.872 * * *$ & $0.822 * * *$ \\
\hline I understand the hardest topics & & & $0.867 * * *$ & $0.800 * * *$ \\
\hline Standardized maths test scores & $0.283^{* * *}$ & $0.300 * * *$ & $0.408 * * *$ & $0.429 * * *$ \\
\hline Observations & 22,246 & 18,231 & 31,594 & 22,772 \\
\hline
\end{tabular}

Standard errors are not presented because the significance level of the regression coefficients is computed with respect to the unstandardized solution. In STATA, the standardized solution is derived from the unstandardized one and standard errors of the standardized coefficients are not-reported.

$* * * \mathrm{p}<0.01,{ }^{* *} \mathrm{p}<0.05, * \mathrm{p}<0.1$ 
Table B3 - Results of SEM model - Structural Model - Unstandardized Solution

\begin{tabular}{|c|c|c|c|c|}
\hline & (1) & (2) & (3) & (4) \\
\hline VARIABLES & SEMV1315 & SEMV1415 & SEMX1314 & SEMX1415 \\
\hline Female & $\begin{array}{c}-0.322^{* * *} \\
(0.015)\end{array}$ & $\begin{array}{c}-0.276^{* * *} \\
(0.018)\end{array}$ & $\begin{array}{c}-0.284^{* * *} \\
(0.013)\end{array}$ & $\begin{array}{c}-0.257 * * * \\
(0.021)\end{array}$ \\
\hline Escs & $\begin{array}{c}0.092 * * * \\
(0.012)\end{array}$ & $\begin{array}{c}0.074 * * * \\
(0.014)\end{array}$ & $\begin{array}{c}0.061^{* * *} \\
(0.009)\end{array}$ & $\begin{array}{c}0.058 * * * \\
(0.016)\end{array}$ \\
\hline North West & $\begin{array}{l}-0.013 \\
(0.027)\end{array}$ & $\begin{array}{c}0.105^{* * *} \\
(0.027)\end{array}$ & $\begin{array}{l}-0.007 \\
(0.018)\end{array}$ & $\begin{array}{l}0.030^{*} \\
(0.018)\end{array}$ \\
\hline Center & $\begin{array}{c}0.078^{* * *} \\
(0.025)\end{array}$ & $\begin{array}{c}0.148 * * * \\
(0.027)\end{array}$ & $\begin{array}{l}-0.000 \\
(0.020)\end{array}$ & $\begin{array}{c}-0.057 * * \\
(0.025)\end{array}$ \\
\hline South & $\begin{array}{c}0.188^{* * * *} \\
(0.023)\end{array}$ & $\begin{array}{c}0.322 * * * \\
(0.026)\end{array}$ & $\begin{array}{c}0.062 * * * \\
(0.017)\end{array}$ & $\begin{array}{c}0.058^{* *} \\
(0.029)\end{array}$ \\
\hline Islands & $\begin{array}{c}0.150 * * * \\
(0.025)\end{array}$ & $\begin{array}{c}0.352 * * * \\
(0.037)\end{array}$ & $\begin{array}{c}0.030 \\
(0.020)\end{array}$ & $\begin{array}{c}0.085^{* *} \\
(0.040)\end{array}$ \\
\hline Vocational High School & & & $\begin{array}{c}-0.220^{* * *} \\
(0.019)\end{array}$ & $\begin{array}{c}-0.229 * * * \\
(0.029)\end{array}$ \\
\hline Technical High School & & & $\begin{array}{c}-0.056^{* * *} \\
(0.015)\end{array}$ & $\begin{array}{c}-0.117^{* * *} \\
(0.025)\end{array}$ \\
\hline High school - father & $\begin{array}{c}0.044 \\
(0.030)\end{array}$ & $\begin{array}{c}0.002 \\
(0.031)\end{array}$ & $\begin{array}{c}0.001 \\
(0.020)\end{array}$ & $\begin{array}{c}-0.009 \\
(0.031)\end{array}$ \\
\hline High school - mother & $\begin{array}{c}0.065 * * \\
(0.027)\end{array}$ & $\begin{array}{l}-0.005 \\
(0.029)\end{array}$ & $\begin{array}{c}0.012 \\
(0.019)\end{array}$ & $\begin{array}{c}0.001 \\
(0.030)\end{array}$ \\
\hline Middle school - father & $\begin{array}{c}0.009 \\
(0.034)\end{array}$ & $\begin{array}{l}-0.023 \\
(0.035)\end{array}$ & $\begin{array}{l}-0.042^{*} \\
(0.022)\end{array}$ & $\begin{array}{c}-0.068 * * \\
(0.034)\end{array}$ \\
\hline Middle school - mother & $\begin{array}{c}0.041 \\
(0.034)\end{array}$ & $\begin{array}{l}-0.010 \\
(0.036)\end{array}$ & $\begin{array}{l}-0.018 \\
(0.022)\end{array}$ & $\begin{array}{l}-0.014 \\
(0.035)\end{array}$ \\
\hline Missing education (father) & $\begin{array}{c}0.071 \\
(0.050)\end{array}$ & $\begin{array}{l}-0.026 \\
(0.052)\end{array}$ & $\begin{array}{c}-0.132 * * * \\
(0.035)\end{array}$ & $\begin{array}{c}-0.159 * * * \\
(0.049)\end{array}$ \\
\hline Missing education (mother) & $\begin{array}{c}0.033 \\
(0.048)\end{array}$ & $\begin{array}{l}-0.023 \\
(0.051)\end{array}$ & $\begin{array}{c}0.015 \\
(0.036)\end{array}$ & $\begin{array}{c}-0.031 \\
(0.051)\end{array}$ \\
\hline Observations & 22,246 & 18,231 & 31,594 & 22,772 \\
\hline
\end{tabular}

Standard errors in parentheses; ${ }^{* * *} \mathrm{p}<0.01, * * \mathrm{p}<0.05,{ }^{*} \mathrm{p}<0.1$

The reference categories are males, living in North East, whose parents have achieved tertiary education. For year 10, the reference category for type of school is Lyceum. 
Table B4- Results of SEM model - Structural Model - Standardized Solution

\begin{tabular}{lcccc}
\hline & $(1)$ & $(2)$ & $(3)$ & $(4)$ \\
VARIABLES & SEMV1315 & SEMV1415 & SEMX1314 & SEMX1415 \\
\hline Female & $-0.180^{* * *}$ & $-0.150^{* * *}$ & $-0.166^{* * *}$ & $-0.147^{* * *}$ \\
Escs & $0.102^{* * *}$ & $0.075^{* * *}$ & $0.070^{* * *}$ & $0.065^{* * *}$ \\
North West & -0.005 & $0.045^{* * *}$ & -0.003 & $0.013^{*}$ \\
Center & $0.033^{* * *}$ & $0.065^{* * *}$ & -0.000 & $-0.026^{* *}$ \\
South & $0.088^{* * *}$ & $0.152^{* * *}$ & $0.031^{* * *}$ & $0.028^{* *}$ \\
Islands & $0.063^{* * *}$ & $0.100^{* * *}$ & 0.013 & $0.036^{* *}$ \\
Vocational High School & & & $-0.096^{* * *}$ & $-0.098^{* * *}$ \\
Technical High school & & & $-0.031^{* * *}$ & $-0.063^{* * *}$ \\
High school - father & 0.022 & 0.001 & 0.000 & -0.005 \\
High school - mother & $0.034^{* *}$ & -0.003 & 0.007 & 0.001 \\
Middle school - father & 0.005 & -0.012 & $-0.024 *$ & $-0.038^{* *}$ \\
Middle school - mother & 0.022 & -0.005 & -0.010 & -0.007 \\
Missing education (father) & 0.032 & -0.010 & $-0.049 * * *$ & $-0.060^{* * *}$ \\
Missing education (mother) & 0.014 & -0.009 & 0.005 & -0.011 \\
Observations & 22,246 & 18,231 & 31,594 & 22,772 \\
\hline
\end{tabular}

Standard errors are not presented because the significance level of the regression coefficients is computed with respect to the unstandardized solution. In STATA, the standardized solution is derived from the unstandardized one and standard errors of the standardized coefficients are not-reported.

$* * * \mathrm{p}<0.01, * * \mathrm{p}<0.05, * \mathrm{p}<0.1$

The reference categories are males, living in North East, whose parents have achieved tertiary education. For year 10, the reference category for type of school is Lyceum. 